\title{
The Xinshu 新書 Reexamined: An Emphasis on Usability over Authenticity
}

\author{
Luo Shaodan \\ Wuhan Irvine Culture and Communication, Wuhan, China \\ Email: shaodan.luo@scirp.org
}

Received November 29 ${ }^{\text {th }}$, 2012; revised December $30^{\text {th }}$, 2012; accepted January $5^{\text {th }}$, 2013

\begin{abstract}
A collection of texts conventionally ascribed to Jia Yi 賈誼 (200-168 BC), the Xinshu 新書 has been subjected to an ages-long debate regarding its authenticity. The present study disclaims the discovery of any adequate evidence to prove the text trustworthy; but it finds the arguments for its forgery ill founded. Rather than present merely an account of this dilemma or attempt to corroborate either position in the debate, this paper argues against the approach in textual criticism that views early texts through a dualistic prism of authenticity vs. forgery. A case of forgery should be established upon no less concrete evidence than should one of authenticity. The mere lack of positive evidence can hardly be regarded or used as any negative evidence to disprove a text. Given the dilemma, the paper suggests treating the Xinshu nonetheless as a workable and even currently reliable source for our study of Jia Yi until that very day dawns upon us with any unequivocal evidence of its forgery detected or, better still, excavated.
\end{abstract}

Keywords: Jia Yi; Xinshu; Western Han; Authenticity; Forgery; Chinese Textual Criticism

\section{Introduction}

The Xinshu 新書 is a collection of texts traditionally ascribed to Jia Yi 賈誼 (200-168 BC). An important figure in the Chinese intellectual history, Jia Yi played an active role in initiating a political reform during the early Han. The form of the extant Xinshu can be traced back to the Song dynasty (9601279) if not earlier. But none of the Song editions survives except by way of Lu Wenchao's 盧文弨 (1717-1796) edition of the Xinshu and Lu's editorial notes therein (Nylan, 1993: p. 162). There are, moreover, texts in the Xinshu that are corrupted. All this resulted in the centuries' long debate over the authenticity of the text. There have been scholars who consider the Xinshu as a case where either a "reckless person" (wangren 妄人) wrote a text and deceptively attributed it to Jia Yi or someone forged a book of Jia Yi by compiling and altering some quotations of Jia Yi gathered from other sources. In this study, I will follow Cohen's suggestion to refer to both kinds of spurious texts as pseudepigrapha ${ }^{1}$.

The view of the Xinshu as a pseudepigrapha is explicit in the Siku quanshu zongmu tiyao 四庫全書總目提要 (Siku tiyao henceforth). Compilers of the Siku tiyao (Siku compilers henceforth) claimed to have identified some other early texts-primarily the Hanshu 漢書— to be the sources based on which the Xinsh $u$ was forged. The unidentified forger, the compilers suspected, forged the Xinshu by fist dividing up some of Jia's essays cited in those other sources, then editing and compiling the

${ }^{1}$ As Cohen (2000: p. 195) observes, “[o]ne aspect of the work of the Ch'ing Dynasty textual scholars [...] was the identification of various types of spuri- ous books. This area of scholarship is called pien-wei 辨偽 'distinguishing the spurious'. The general term for such books is wei-shu 偽書, which is often translated as 'forgery'. However, 'pseudepigrapha' (writings of falsely ascribed authorship) is a more appropriate translation because 'forgery', with its implication of intentional fraud, applies to some types of wei-shu but not to all." divided passages into 58 chapters, and finally putting each of the 58 under an imposed title in order to falsely establish it as a chapter. The Siku compilers opined that the forger's motive was to match the total of the forged chapters with the number recorded in the bibliographic treatise of the Hanshu (i.e. Hanshu 30).

From late 1950s to early 1960s, Chen Weiliang 陳煒良 (1958) in Hong Kong and a team of four accomplished scholars in Peking University (i.e. Sun Qinshan et al., 1961) each provided a comprehensive summary of the debate. Both raised quite a few original and cogent points. After reviewing the same set of contending arguments, they each arrived at a conclusion in opposition to the other's. The four scholars in Beijing conclude their study by arguing for the authenticity of the Xinshu. Following the four scholars, Wang Zhouming 王洲明 (1982) conducted a similar collative comparison and reached the same conclusion. The four scholars' major points are incorporated in Wang Zhouming's study and presented along with Wang's substantial original findings. One can thus legitimately treat Wang as a major defender of the Xinshu in modern China. Without being informed of Chen Weiliang's insightful challenge, Wang Zhouming, however, did not have a chance to deepen his discussion.

Examining a textual issue invariably involves ascertaining the date of a text. The language of a text has long been an area where scholars commence their search for evidence. In the past few years, there have been scholars who attempted linguistic approach to the received Xinshu, looking for what the text might reveal linguistically about its date. Wang Zhouming, for one, included a linguistic discussion of a moderate scope in his aforementioned research. In Europe and at the turn of the millennium, Rune Svarverud conducted a much more extensive research in this respect. His attempts significantly contribute to the linguistic study of the extant Xinshu. But, his study, as Luo 
Shaodan (2002) points out, falls short of providing adequate proofs $^{2}$. More work is yet to be done in this field.

Besides language, other textual issues have also been brought into focus. Some textual features were particularly cited as evidence of forgery. They include the textual corruption, the flawed writing style, the lack of reference to the Zuozhuan 左 傳, and the mismatch between some quotes of Jia Yi in the Hanshu 漢書 and their counterparts in the Xinshu.

The discussion on writing style often touches upon the textual mismatch between the Xinshu and Jia Yi's quotes elsewhere. Such discussion adequately demonstrates scholars' difficulty in maintaining objectivity when they face the current lack of transmitted or excavated manuscript as a reliable reference point. The afore-mentioned four scholars in Peking University, for instance, conducted a textual comparison between the Xinshu and the quotes of Jia Yi in the Hanshu. They considered the Xinshu authentic because they found the texts in the Xinshu smoother and more consistent in style than the quotes in the Hanshu. But, precisely the same kind of comparison left Chen Weiliang with an opposite impression about the writing style of the Xinshu. He concluded that the Xinshu was forged by copying those quotes in the Hanshu. Likewise, Yao Nai 姚疆 (1732-1815) also considered the Xinshu spurious partly because, to him, the Xinshu did not seem to present as good a writing style as did its textual counterparts in the Hanshu. Their conflicting views, interestingly, converged on a basic assumption of Jia Yi's perfection in writing style. Stemming from the assumption was a conviction that, between the Xinshu and those quotes, the better written text would necessarily be the original text. But one may find the common ground questionable at a time before the perfection of Jia Yi's writing style can be established in the first place.

Chen Weiliang, in addition, noted that the spuriousness of the Xinshu was evidenced in its lack of reference to the Zuozhuan, because such absence was impossible for someone like Jia Yi, an official-scholar with acclaimed expertise in Zuozhuan study in his generation. In the present study, I will point out that such absence is hardly inconceivable once we take into consideration the time in which Jia Yi had lived, a time when neither the Zuozhuan School of historical studies nor the practice of citing canonical texts was favorably received in political life.

Since none of the above approaches has yet shown unequivocal evidence, the present study will seek hard evidence primarily in the physical layout of the text. The insufficiency of relevant excavations may impede further progress in scholarship. This study stuggests that progress can nevertheless be made on the basis of received texts. The evidence of early text can be detected in what we may call embedded end title for passages in the extent Xinshu. Meanwhile, the paper would disclaim any intention to establish a case of authenticity. What

\footnotetext{
${ }^{2}$ See Luo Shaodan (2002). Svarverud devotes 61 pages to examination of the salient linguistic features in the extant version of the Xinshu and thereby concludes that the Xinshu is authentic. Assuming the ignorance of medieval literati-particularly medieval text forgers—about early Chinese, he applies to the Xinshu the linguistic criteria developed by Bernard Karlgren for identifying early Chinese texts. Without challenging Svarverud's view regarding the authenticity of the Xinshu, Luo cautions that, since the literary language in the Han dynasty constitutes a transition from early to medieval Chinese, Karlgrenean method is inadequate in textual studies on documents ascribed to the Han dynasty. Luo finds out that many salient features that Svarverud identified in the language of the extant Xinshu can be found in Han Yu's 韓 愈 (768-824) essays.
}

it opposes is the adherence to the dichotomy of authenticity and spuriousness where the Xinshu is concerned.

The present study, therefore, would point out that, for all the lack of substantial evidence to authenticate the Xinshu, it is unadvisable to label the Xinshu as pseudepigrapha. And this paper will question the viability of such a practice as treating the textual corruption of the extant Xinshu to be evidence of its forgery.

Following this introduction, the first section of this article tackles such fundamental questions as what the Xinshu is and what it was thought to be. I find that, first, no pre-modern editions of the Xinshu contain Jia Yi's literary works except in an appendix in some cases. Second, the evidence I examine does not support the proposition that the Xinshu was compiled on the basis of Jia Yi's quotes in the Hanshu.

The second section begins by summarizing the corrupted condition of the Xinshu text. Close attention is paid to the peculiar way in which some parts of the text are divided and how the peculiarity aroused the suspicion of forgery. The discussion proceeds to relate such peculiarity in the Xinshu to the formats of silk and bamboo texts in the early times. I will focus on the way embedded end titles were used in early texts and the change they underwent. The section cites concrete evidence to suggest that originally all or some of the chapters in the extant Xinshu were merely passages rather than freestanding texts. They were either mistaken for titled essays (i.e. chapters) or intentionally but erroneously treated as chapters in later editions. Hence the peculiar divisions of some of the texts in the Xinshu are hardly indicative of forgery.

The third section examines the views of Yao Nai and the Siku tiyao. Both question the authenticity of the Xinshu. Both have inspired later debates, including Yu Jiaxi's 余嘉錫 (1883-1955) forceful refute of the Siku tiyao. But unlike the Siku compilers, who would give credit to the part of the Xinshu that bore no textual parallel to the Hanshu, Yao Nai considered the Xinshu entirely untrustworthy. I will argue that Yao's point proceeded from a misinterpretation of both the Xinshu and the Hanshu.

The fourth section discussed Chen Weiliang's textual study. To my knowledge, there has been hardly any response to Chen's challenge except Svarverud's book. In this section I will, besides introducing Svarverud's points, question the validity of the evidence Chen cites, which includes the verbosity of the Xinshu text and the lack of mention of the Zuozhuan in the Xinshu.

In the conclusion, I, on the one hand, acknowledge the insufficiency of current evidence to authenticate the Xinshu. On the other hand, I argue that the reliability of the extant Xinshu can be recognized on the sole basis of the inadequacy of all the arguments that are hitherto made to prove the Xinshu spurious.

The edition of the Xinshu that I use is primarily the one compiled by Yan Zhenyi 閻振益 and Zhong Xia 鐘夏 (2000). This edition is based upon the Jifu 吉府 (1515 AD) edition, which is a Ming-dynasty edition and whose source, according to Yan and Zhong (2000: p. 5), can be traced far back into premodern times because of some identified features of pre-Song scripts. Other editions that I use include the Siku quanshu edition and Lu Wenchao's Baojing Tang 抱經堂 edition. Subsumed under this latter edition are a reproduction of the Baojing Tang edition in 1937 by Shangwu Yinshuguan, a modern edition by Wu Yun 吳雲 and Li Chuntai 李春臺 (1989), and 
another modern edition by Wang Zhouming and Xu Chao 徐 超 $(1996)^{3}$. Fang Xiangdong’s 方向東 (2000) modern edition, which collates several editions, has also been accorded close attention.

\section{Xinshu or Not Xinshu?-Two Criteria}

As observed above, the Xinshu is said to have been forged on the basis of the citations of Jia Yi in the Hanshu. But in addition to the Xinshu, there have been other monographs attributed to Jia Yi. Some are indeed composed of the quotes of Jia Yi in the Hanshu. We thus need to make certain we are not discussing one of those other books when we actually mean to examine the Xinshu. In the face value, the confusion seems unlikely to occur, for different books are differently titled. However, title turns out to be an inadequate means of identification, because "Xinshu" was not an original title of that corpus of essays attributed to Jia Yi. This title occurred as late as the 6th century (Wang Zhouming, 1982: p. 17). It is thus necessary to examine the identity of what came to be the extant Xinshu.

Regarding this issue, Wang Zhouming holds a rather broad view. Having traced the record of Jia Yi's works in the bibliographical treatises of dynastic histories as well as such Songdynasty bibliographical catalogs as the Chongwen Zongmu 崇 文總目 and Zhongxing Guan'ge Shumu 中興館閣書目, Wang concludes,

The above records indicate that the work of Jia Yi was transmitted all along from the Han Dynasty to the Song Dynasty. [Its] title varied during the transmission: [It] was known sometimes as the Jia Yi, sometimes as the Jiazi, sometimes as the Jia Yi ji, and sometimes as the Jia Yi xinshu. What [also] varied was the textual division: [It] could be in 2 juan, 4 juan, 9 juan, 10 juan, or 19 juan. And there lacked a uniformed way of categorizing it. [The monograph] was categorically treated sometimes as [a text of] Confucian School and sometimes as [one of] the Miscel- laneous School. 上述著錄說明, 賈誼的作品, 從漢代到宋代都一直流傳。在流傳中, 名稱有變化, 或稱賈誼，或稱賈子，或稱賈誼集，或稱賈誼新書; 卷數有變化, 或二卷, 或四卷, 或九卷, 或十九卷; 歸屬亦不同, 或歸儒家, 或歸雜家 (Wang Zhouming, 1982: p. 18).

Apparently, Wang implies here that the monograph under discussion could also be known as the Xinshu; because, in his citation of the Zhongxing guange shumu, "Xinshu" was the adopted title. Wang (1982: pp. 19-20) later suggested that the extant Xinshu and the "ancient editions" (guben 古本) of the book came from the same source. So it is obvious that, along this long chain of identifications, if any of the monographs is found to be problematic, the Xinshu will be automatically subjected to suspicion.

Wang Zhouming's chain of identifications noticeably includes some text corpus categorized under literary sections in the bibliographical treatises of dynastic histories. Wang (1982: pp. 17-18), for instance, includes a 4-juan Jia Yi ji, a 2-juan Qian Han Jia Yi Ji, and a 2-juan Jia Yi Ji in, respectively, Suishu 35, Jiu Tangshu 47, and Xin Tangshu 60. These mono-

${ }^{3}$ Both teams of modern scholars declare that they have largely kept the text of Baojing Tang 抱經堂 edition intact in their editions (see Wu \& Li, 1980: p. 358; Wang \& Xu, 1996: p. 4). graphs are all in the category of literary works. My study shows that although the Xinshu circulated under different titles, Jia Yi's literary works were not included except as an appendix in some cases. As Svarverud observes,

[T] he texts attributed to Jia Yi consisted of two main bodies of texts: The memorials written by Jia Yi himself as suggestions and grievances on the current situations in the empire of Western Han times; and the more philosophical and cosmological texts recording the words of Jia Yi based on his teachings and speeches conducted by himself, or his disciples and relatives shortly after his death-most probably both (Svarerud, 1998: p. 8).

Except in the Songshi 宋史, where a 10-juan Jia Yi xinshu is categorized as a text of Miscellaneous School, the collection that Svarverud observed is invariably categorized in the section of rujia 儒家 in both dynastic histories and other bibliographical sources. Examples include a 58-pian Jia Yi in the Hanshu, a 10juan Jia Zi in the Suishu, a 9-juan Jia Zi in the Jiu Tangshu, a 10-juan Jia Yi Xinshu in the Xin Tangshu, a 19-juan Jiazi in the Chongwen zongmu, and a 10-juan Xinshu in the Junzhai dushu zhi 郡齋讀書志.

In his bibliographical catalog, the Yuhai 玉海, Wang Yinglin 王應麟 (1223-1296) regarded, firstly, the three Jia Yi books recorded in those dynastic histories and, secondly, the Xinshu recorded in the Zhongxing guange shumu as texts of one and the same tradition. He provided a list of all the essays in the version of the Xinshu in his time, which overwhelmingly corresponds to the table of contents of the extant Xinshu. On that list, there are no works of literature. Moreover, we see on the list a considerable amount of texts not found in the Hanshu. A text of this tradition is exemplified by Lu Wenchao's edition of the Xinshu, which consists of 58 philosophical and political essays attributed to Jia Yi. But among the 58 essays, two are completely missing except for their titles. The 58 pieces are divided into such categories as shishi 事勢, lianyu 連語, and zashi 雜事. Some editions, such as Lu Wenchao's, include Jia Yi’s Hanshu biography.

If anyone either suggests a different line of textual transmission or introduces a different monograph, s/he needs to first define his/her position to the tradition identified by Wang Yinglin. Otherwise, s/he may risk causing confusion in schoolarship by introducing other books into the tradition without giving a notice. And that may lead to the error of discussing the authenticity issues of a wrong book.

Since Wang Yinglin identified the tradition without suggesting any exhaustive list of books, caution should be taken when one attempts to extend the list by adding books. Although difference in title is of little importance in this case, it must be noted that any book we add should meet the following two criteria reflected in Wang Yinglin's bibliographical notes and table of contents. First, the book attributed to Jia Yi should be categorized in a non-literary section in pre-modern bibliographical sources. Specifically it should fall into the section of philosophical works - be it "Confucian School” or "Miscellaneous School. What this criterion entails is the absence of literary works except, as occasionally is the case, in an appendix. Sec- ond, the contents of the book, if known, should not be limited to the memorials of Jia Yi quoted in the Hanshu. It would be desirable that the book we find meets both criteria, because the tradition that Wang Yinglin identified would repu- 
diate books that meet either criterion alone. Therefore, once we add a book that fails to meet both criteria, efforts must be made to explain why we still consider the book affiliated with the extant Xinshu. This simple rule can save us from wasting our time on a book that we never mean to discuss.

Below we will examine how Jia Yi's literary works are related to the Xinshu.

\section{Jia Yi's Literary Works and the Xinshu}

Besides the collection of Jia Yi's works categorized in the section of philosophy, there are other collections under Jia's name but categorized in such literary sections as fu-poetry (e.g. Hanshu 30), ji 集 (e.g. Suishu 35) and bieji 別集 (as in both Tangshu). We consider those books outside the tradition of the Xinshu because they are categorized separately from the books in the tradition identified by Wang Yinglin.

But, since Jia Yi stands out in Chinese history as both a political thinker and a literary figure, could it be that, in each of those dynastic histories, a single text corpus ascribed to Jia Yi was twice entered with each entry under a different title plus a different catalog and divided into a different number of juan? There can be no definite answer to this question. This is a matter of likelihood.

The practice of multi categorization, to start with, would be bibliographically confusing. It would seem no more advisable to us than it did to pre-modern historians. In Hanshu 30, Ban $\mathrm{Gu}$ 班固 (32-92) is found to be meticulous in this regard. Hanshu 30 was based on the Qilue 七略 (cf. Hanshu, p. 1701; Suishu, pp. 905-906), a lost bibliography compiled by Liu Xin 劉歆 (fl. 53-23 BC). In Hanshu 30, Ban Gu left some unequivocal notes where categories in the Qilue were altered ${ }^{4}$. Although we are not certain exactly how systematic his categorization and notes may be, oftentimes what seems to be double categorization is nonetheless conventionally treated as an indicator of different bibliographical identities ${ }^{5}$. It is thus unjustifiable to treat one monograph in the category of philosophy as identical with another in the section of literature just because they are ascribed to the same author, hence our first criterion.

The first criterion, to recall, also entails the absence of Jia Yi's literary works except in an appendix. In Hanshu 30, there are a 58-pian Jia Yi categorized under rujia and a 7-pian Jia Yi under the fu-poetry ${ }^{6}$. None of the fu-poems is included in Lu Wenchao's edition of the Xinshu. And, in a note on Jia Yi's

\footnotetext{
${ }^{4}$ For instance, beneath the category of zhuzi 諸子, there is a note saying “with a 25-pian Cuju removed [from here].” 出蹴鞠一家, 二十五篇 (Hanshu, p. 1745), while beneath the sub category of Jiqiao 技巧,he added the following note, "with a redundant Mozi omitted to enter a Cuju [in its place].” 省墨子重, 入蹴鞠也 (Ibid. p. 1762). The same kind of mutually referential notes can also be found between the sub categories of Quanmou 權謀 (Ibid. p. 1757) and $L i$ 禮 (p. 1710) for the book Sima Fa 司馬法. According to Yan Shigu's 顏師古 (581-645) note to Hanshu 30, words such as "removing” 出 and “entering” 入 in Ban Gu's notes indicate Ban Gu's modification of certain bibliographical categories in the Qilue (p. 1706). There are cases where Ban Gu removed certain books from a category because he found them double categorized in the Qilue; though both Qilue categories made sense. His treatment of "a redundant Mozi” may serve as a good example. Since the Mozi had already been put under the category of Mojia 墨家 (see p. 1738), Ban Gu removed its other entry under the sub category of Jiqiao in the section of Bing 兵, and wrote the note we just quoted above, though the other category, Bing: Jiqiao, also makes sense because of those chapters in the Mozi-specifically 11 chapters in Juan 14 and Juan 15-that feature detailed discussions of military techniques.
}

works in Hanshu 30, Wang Yinglin wrote, "[Under the category of] rujia [in] the [bibliographical] treatise [of the Hanshu, there is a] 58-pian Jia Yi. Besides, there are seven pian of fu-poems.”志: 儒家: 賈誼五十八篇。又賦七篇 (Wang Yinglin, 1987: Juan 55, p. 3a). Wang Yinglin's observation was echoed almost verbatim by Zhao Ximing 趙曦明 (1705-1787) (1937: p. 86), who put the following note about the records of Jia Yi's works in Hanshu 30, “[in] the bibliographical treatise [of the Hanshu], there are 58 pian [under] rujia. Besides, there are seven pian of the fu-poems.”藝文志: 儒家: 賈誼五十八 篇。又賦七篇. Their use of the word “besides” 又 is obviously of great significance; because the word indicates their conscious categorical separation of the seven pian fu-poems from the 58-pian Jia $\mathrm{Yi}^{7}$.

We have mentioned that certain versions of the Xinshu might include Jia Yi's literary works in an appendix. But such versions are normally considered as “other versions” 別本. He Mengchun 何孟春 (1474-1536) once provided an annotated table of contents for his edition of the Xinshu in the Ming Dynasty (see Yan \& Zhong, 2000: pp. 492-493). The last volume, according to the table, contains five fu-poems of Jia Yi. It was He Mengchun himself that referred to this edition as a bieben (Ibid, p. 492). Qi Yuzhang 祁玉章 (1969: p. 45) further noted that He Mengchun's edition differed from other editions in the

${ }^{5}$ In Hanshu 30, a 29-pian Shangjun 商君 and a 27-pian Gongsun Yang 公 孫鞅 are separately categorized though both were attributed to the pre-Qin statesman Shang Yang 商鞅 (cf. Hanshu, p. 1735, 1757). The same holds true with a 2-pian Pang Xuan 龐煖 and a 30-pian Pang Xuan, both of which are apparently ascribed to the pre-Qin military commander and theorist Pang Xuan (cf. Hanshu, p. 1739, 1757) In these two cases, Ban Gu did not put any note regarding how each book is related to its suspected counterpart in a different category. It is to be noted that cases like this are rare. Moreover, what the categorical distribution of Li Kui's 李悝 works exemplifies is a case in which books attributed to the same author, once categorized separately, are usually treated as different books rather than simply as different versions of a same book. In Hanshu 30, there are a 7- pian $\mathrm{Li} \mathrm{Ke}$ 李克, a 32-pian Li Kui, and a 10-pian Lizi 李子 respectively under the categories of rujia, fajia 法家, and bing quanmou 兵權謀. All these books are ascribed to the pre-Qin statesman Li Kui, though all had been lost by the time of Suishu 35. Yet, because these books were differently categorized in Hanshu 30, they are considered as three different books (see Gu Shi, 1987: pp. 99, 133, 194; Zhang Shunhui, 1990, p. 238).

${ }^{6}$ Yao Minghui 姚明煇 (fl. 1914) provided specific titles for five of the seven fu-poems, such as “Diao Qu Yuan fu” 局屈原賦, “Funiao fu” 鵬鳥 賦, etc. (see Yao Minghui, 1933: p. 146). There are only two pian that Yao did not find. But there is a “Diao Xiang fu" 弗湘賦 recorded by Chen Zhensun 陳振孫 (1983: vol. 674, p. 694a) in the Song Dynasty. It is not certain whether "Diao Xiang fu” is an alternative title for "Diao Qu Yuan fu."

${ }^{7}$ Since the main-body text of the Xinshu normally begins with Jia Yi’s "Guo Qin lun” 過秦論, one may wonder whether this exemplifies a case where the Xinshu includes a work of literature. This question derives from the fact that, in pre-modern times, “Guo Qin lun” was occasionally considered as a work of the fu 賦 poetry (cf. Qian Zhongshu, 1979: p. 888). The fact is, however, "Guo Qin lun” is not exactly a fu-poem. Rather it is merely a case where "Mr. Jia [Yi] presents [a piece of] exposition that resembles a fu [poem].” 賈生作論而似賦 (Ibid. p. 891). I think a parallel case could be found in Yang Xiong's 揚雄 (53 BC-18 AD) essay “Jiechao” 解嘲. “As an essay featuring parallelism,” observed Yang Shuda 楊樹達 (1984: p. 677), “certainly 'Jiechao' came to be known as a fu-poem among later generations [after Yang Xiong and Ban Gu].” “解嘲”行文偶儷, 稱賦自是後世 之事.” Such practice of posterior labeling speaks of an example in which scholars, from hindsight, "applied the terminology of later-generation literary stylists to [their] discussion of Ban [Gu's] book.”用後世文章家文法說 班書 (Yang Shuda, 1984: p. 677). Hence it would be hardly correct to assert that "Guo Qin lun” and “Jiechao" were meant to be fu-poems at the time when they were composed. 
way the texts were divided into volumes. Evidently, even in this "other edition," the section of Jia Yi's literary works is nonetheless kept outside the main-body text and is reduced to an appendix ${ }^{8}$. This tradition seems to be well preserved in modern times as well. In their edition of the Xinshu, Yan Zhenyi and Zhong Xia put Jia Yi's fu-poems in an appendix, to which the two modern scholars gave such a sub-title as "The fu-poems and Scattered Texts Not Included in the Xinshu.” 新書未收文 賦及佚文. This title confirms our view that Jia Yi's literary works are not included in the main-body text of the Xinshu.

\section{The Xinshu and the Quotes of Jia Yi in the Hanshu: The Second Criterion}

In Xinshu study, scholars unanimously consider Chen Zhensun 陳振孫 (1179-1262) as the first one who claimed to have found the Xinshu spurious ${ }^{9}$. Those who question the authenticity of the Xinshu would work hard to substantiate Chen Zhensun's view. And those who trust the Xinshu would often begin their discussion by refuting Chen Zhensun. But a perusal of Chen Zhensun's annotation would lead us to discover that the 11-juan Jiazi that he examined failed to meet at least one of our criteria. We thus suspect that this Jiazi, regardless how spurious it might be, had nothing to do with the Xinshu. Let us quote Chen Zhensun in full and take a close look.

The Jiazi [in] 11 juan. Note: According to the Chongwen Zongmu, the bibliographical treatises of the Suishu and the [Jiu] Tangshu both have [Jia Yi's book] in nine juan. The treatise of the Xin Tangshu has it in 10-juan. This edition is [in] 11 juan [and hence] suspicious of error. [Its ascribed] author is Jia Yi from Luoyang, [who served as] grand tutor of King of Changsha in the Han Dynasty. [The compilation consists of] 58 pian [according to] the bibliographical treatise of the Hanshu. This book begins with "Guo Qin lun” and ends with "Diao Xiang fu." The rest [of it] is all composed of excerpts from the Hanshu. Moreover, in Volume 11, [there is a] "Biography of Jia Yi” abridged [from the Hanshu]. Those parts that are absent from the Hanshu are invariably shallow, motley, and [hence] unworthy of any attention. [Therefore the book] could be anything but Jia Yi’s original work. 賈子十一 卷。案: 崇文總目云隋唐志皆九卷。新唐書藝文志作 十卷。此本作十一卷, 疑誤。漢長沙王太傅洛陽賈誼 撰。漢志五十八篇。今本首載過秦論, 末為尔湘賦, 餘皆錄漢書語, 且略節誼本傳於第十一卷中, 其非漢 書所有者, 䡛淺駁不足觀, 決非誼本書也 (Chen Zhensun, 1983: Vol. 674, p. 694a).

Based on Wang Yinglin's notes and table of contents, our second criterion stipulates that in no case can there be an edition of the Xinshu with its contents limited to the memorials of Jia Yi in the Hanshu. From Chen Zhensun's account, we learn that the book he witnessed featured a main-body text that "begins with 'Guo Qin lun' and ends with 'Diao Xiang fu'.” In addition, there was an abridged biography in Volume 11 that was included presumably as an appendix. The rest of the book, as we are told, "is all [emphasis added] composed of excerpts

\footnotetext{
${ }^{8}$ According to Chao Gongwu 沓公武 (fl. 1151-1161), there are also “certain [versions of the Xinshu that] include [Jia] Yi's biography in Hanshu as an appendix.” 或取漢書賈誼傳附於後 (Chao Gongwu, 1983: p. 214b).

${ }^{9}$ Dates of Chen Zhensun's life span are provided according to He Guangyan's 何廣棪 (2001) research.
}

from the Hanshu" with only a few occasional exceptions. Then how can this 11-juan Jiazi be an edition of the Xinshu? How can this book possibly be affiliated with the tradition that Wang Yinglin identified? Chen Zhensun was certainly right when he judged the 11-juan Jiazi to be a pseudepigrapha. It is us who have misread Chen Zhensun and resultantly formulated an erroneous impression that by denouncing the 11-juan Jiazi, Chen Zhensun was questioning the authenticity of the Xinshu.

\section{Textual Division and the Textual Corruption of the Xinshu}

The Xinshu is known to consist of 58 chapters. But none is mentioned in early bibliographies. Wang Yinglin's Yuhai is the first known source that has listed the 58 titles. Since the Xinshu is a collection of essays, each essay constitutes a titled chapter. There are two titles whose subordinate texts were lost early. Fifty-eight is also the number for chapters recorded in the Siku tiyao. The Siku compilers indicated that only 55 chapters had survived the long process of transmission from the Song dynasty ${ }^{10}$.

In the late 1990's, Rune Svarverud (1998: pp. 8-11) listed those 58 chapters in his book-including the two titles with missing texts-along with their distributions among the ten juan of the extant Xinshu. This number for the chapters matches the number recorded in Hanshu 30 (cf. Hanshu, p. 1726).

\section{Physical Condition of the Text}

Among the received 50 some chapters, some do not look like chapters. And there are numerous corrupted passages, which gives rise to quite a few cases of contextual mismatch and gaps in logic (Chen Weiliang, 1958: pp. 4-5). Yet such an imperfect version, as we know now, is the remainder of several re-editions and reproductions over time, especially those in the Tang and Song times (Svarverud, 1998: p. 33).

As a concrete example, in a chapter entitled "Qin shu wei luan” 親疏危亂, we encounter a rather abrupt beginning like this,

There is something that Your Majesty would not do now. [I,] Your subject [,] would not dare present [anything] less than the entire truth [regarding the current] situation. [Let us] suppose that the sub-celestial terrain were the same as an earlier time when] Marquis of Huaiyin stayed enfeoffed at Chu, Qing Bu stayed enfeoffed at Huainan, Peng Yue stayed enfeoffed at Liang, Han Xin stayed enfeoffed at Han, Zhang Ao stayed enfeoffed at Zhao, Guan Gao stayed [in his position] as a minister, and Lu Wan stayed enfeoffed at Yan; [let us further suppose that] Chen $\mathrm{Xi}$ were still in Dai. [In a word, let us] suppose that these few lords were all well and alive, remaining at their individual fiefs. Had Your Majesty ascended to the throne at a moment like that, could Your Majesty consider Yourself safe? [I,] Your subject, know as a fact that Your Majesty could not. 陛下有所不為矣, 臣不敢不畢陳事制。假 設令天下如暴昔也, 淮陰侯尚王楚, 黥布王淮南, 彭 越王梁, 韓信王韓, 張敖王趙, 貫高為相, 盧綰王 燕, 陳狶在代, 令六七公諸皆無恙, 案其國而居, 當

\footnotetext{
${ }^{10}$ Compiled on the basis of Lu Wenchao's edition, the extant Xinshu comprises 56 or 55 chapters, depending on whether the "Guo Qin lun No. 2" and “Guo Qin lun No. 3” are combined.
} 
是時, 陛下即天子之位, 試能自安乎哉? 臣有以知陛 下之不能也 (Jia Yi, 1937: pian 23, p. 32).

Wu Yun and Li Chuntai share Lu Wenchao's view that the first sentence makes a rather odd beginning ${ }^{11}$. The Siku compilers, Chen Weiliang, and Huang Yunmei all take this kind of textual corruption to be indicative of a case where the Xinshu was forged by first splitting up the quotes of Jia $\mathrm{Yi}$ in the Hanshu and then artificially imposing a title on each split passage. To the Siku compilers, such corrupted condition seemed to suggest that the Xinshu was forged on the basis of a number of lengthy quotes of Jia $\mathrm{Yi}$ in other early texts, especially the Hanshu and the Da Dai liji 大戴禮記.

This view came to be widely accepted in the 20th century. Cai Tingji 蔡廷吉 (1984: p. 27), for one, observed that, since the Song times at the latest, it had been a common practice among pre-modern editors of the Xinshu to make up a total of 58 chapters so as to match this record in Hanshu 30. Huang Yunmei (1980: p. 263) and, especially, Chen Weililang (1958: pp. 4-5) are arguably the most prominent advocators of the view expressed by the Siku compilers. They both suggested that the Xinshu was artificially created by collecting, altering, and finally imposing titles on, the various quotes of Jia Yi's texts in the Hanshu.

Without subscribing to this skepticism, Svarverud (1998: p. 8, 2000: p. 13) suggested that certain chapters might have each been deliberately divided up into 2 or 3 passages in order to make up the number of 58. He rightly observed that the relation was "very hard to establish now" between the 55 or 56 chapters in the extant Xinshu and the unidentified 58 pian mentioned in Hanshu 30. Such disorder in the Xinshu significantly adds complexity and would hence easily arouse doubts. As Gardner observes,

[T] he textual division of a Chinese-as of a Westernbook is normally dictated by the development of the subject. Any alteration in such division must ordinarily reflect either omission of some part of the original text, addition to it, or a complete recasting of the former treatment of the subject .... It follows that ... alteration in the number of pien, sections, in an ancient text, or of juan, now chapters, in a modern one, both of which are subject divisions, is ... a matter of grave concern ... If, then, we detect a variation in the textual division of a Chinese work in the history of its transmission, it behooves us to inquire carefully for an explanation (Gardner, 1961: pp. 41-44).

But forgery can hardly be the only explanation. One factor could be the physical damage the text suffered. Skeptics of the $X i n s h u$ have never convincingly ruled this out. Take the Xinshu text we just quoted. Its abrupt beginning and short length make it look more like a miss-located passage than a freestanding text. The earliest printed editions of the Xinshu were, like many other pre-modern texts, woodblock editions in the Song dynasty (Qi Yuzhang, 1969: p. 44; Wang Zhouming, 1982: p. 17; Cai Tingji, 1984: pp. 53-54). Chinese texts previous to woodblock printing existed in large amount as scripts on bamboo slips or silk. In cases where a long text was inscribed on several separate pieces of slips or sheets of silk, any accidental derangement of the chunks and pieces could result in serious textual disorder (Yu Jiaxi, 1958: pp. 546-547).

\footnotetext{
${ }^{11}$ See Wu \& Li, 1989: p. 104. Lu Wenchao's opinion can be found in Lu's note in Jia Yi, 1937: p. 32.
}

Besides, late Professor Zhang Shunhui 張舜徽 (1962: pp. 28-29) pointed out that, after the emergence of wood-engrave printing, book producers would make a point of ensuring an economical use of engraving materials at the expense of the physical layout of ancient editions. Zhu Taiyan 朱太岩 (1989: p. 47) also noted that, in the age of woodblock printing, book producers tended to seek to create new, and hence change the old, text formats for the mere purpose of making their products look appealing to their customers. The text format we see in woodblock printing is therefore not always a faithful replica of an early edition. Chen Weiliang is right in noting that some chapters look fragmented. But, to consider the fragmentation indicative of spuriousness is to over stretch the significance of the evidence ${ }^{12}$. Skeptics of the Xinshu never adequately explicated to what extent textual fragmentation could be considered evidence of forgery.

But, if it is merely a passage rather than a chapter and if the title is not something artificially imposed by a forger, why else is there a title for this passage?

\section{Embedded Passage Titles and Its Possible Application in the Xinshu}

The answer can be found in what we may call passage titles or embedded end titles found in bamboo and silk texts up to the Han times, if not later. As passage titles instead of chapter titles, they were positioned at the end of each passage. I will argue that this format and the change it underwent can adequately account for both the peculiar textual division and the textual corruption in the received Xinshu.

The Han edition of the Yili 儀禮 suggests a format that may confuse an inexperienced medieval or modern reader ${ }^{13}$. Since this text is a Han edition, one cannot rule out the possibility this might have been one of the formats adopted in the early collection of Jia Yi's works.

Some pre-modern scholars already noted that, in early Chinese texts, there were often subtitles assigned to individual passages within a chapter (Zhang Shunhui, 1962: pp. 35-37). In the 1940s, Professor Zhang Shunhui was among the first few modern scholars who provided comprehensive accounts of this format, observing in particular that the format could be found in early texts such as the Xunzi and the Lüshi chunqiu ${ }^{14}$ (Both texts are noticeably pre-Qin texts compiled during the Western Han). Later on, there were more scholars following their steps. Knoblock (1988: Vol. 1, p. 113), for one, noted that "the Lü edition (of the Xunzi) divided the text of each book into para-

\footnotetext{
${ }^{12}$ Much as Chen Weiliang maintained that the textual problems could not have been the result of scattered bamboo slips with rotten strings or of a delinquent script copier, he did not provide any detailed examples to support his point. Chen has provided two detailed charts to compare between the Xinshu and other documents, especially the Hanshu. But, with those charts, Chen makes no attempt to examine the fragmentation found in the Xinshu. (see Chen Weiliang, 1958: pp. 4, 6-21).

${ }^{13}$ It is a format in which all the chapter numbers and chapter titles were inscribed on the backside of each chapter's first [bamboo] slip. By that we mean on the reverse side of each chapter's first line. Long chapters of over dozens or one hundred slips were numbered on the back of the first slip whereas their titles were scribed on the back of the second slip (Chen Mengjia, 1980: pp. 301-302).

${ }^{14}$ For instance, Professor Zhang Shunhui (1990: p. 184) once observed that the Lüshi chunqiu 呂氏春秋, another text from the State of Qin, was the first early Chinese text that was known to have adopted this format. From Professor Zhang's preface, we learn that the source where he made this observation was originated from his manuscript in 1946.
} 
graphs covering single topics. Some of these paragraphs contain embedded titles.”

Embedded end titles can also be found in excavated texts. In the Shuihudi Qinmu zhujian 睡虎地秦墓竹簡 (4th?-3rd? BC), end titles like “chuli lü” 除吏律，“chu dizi lü”除弟子律, “Wei hulü” 魏戶律, and “Wei benming lü” 魏奔命律, etc. all suggest pre-Han use of such titles than in the Han dynasty ${ }^{15}$. Other examples, as Yates noted, can be found in the Huang-Lao texts excavated at Mawangdui in mid-southern China (Yates, 1997: pp. 197-198). Since the Shuihudi and Mawangdui texts are respectively Qin and Han scripts, it is safe to consider the use of such titles as a common practice during the Qin-Han period at the latest ${ }^{16}$. In some early texts, titles and subtitles are found respectively at the end of an essay and the passages or paragraphs in the essay (Wang Liqi, 1999: pp. 265-267). In others, there can be an essay title that covers each essay while there are subtitles placed at the end of each passage (Jiang Boqian, 1990: pp. 119-120). It is not known whether the titles were provided by the authors or imposed by the compilers of the texts. But one thing is certain: Even if they proved to be posterior impositions, it would not mean the text itself is spurious ${ }^{17}$.

These titles were, admittedly, not well preserved in later editions of early texts. And this format could easily mislead those who reproduced early texts in pre-modern times, resulting in their erroneous presentation of early texts. Some scholars (e.g. Gu Yanwu, 1990: pp. 908-909; Zhang Shunhui, 1962: p. 35) imputed the mishandling of these titles to the medieval and later editorial confusions that mistook those embedded end titles for part of the main-body text.

If an editorial note by Lu Wenchao is right, we may say such editorial mistake can indeed be detected in an essay entitled “Wumei” 五美 in the Xinshu. In Lu's edition, this chapter ends with a sentence that reads, "Your Majesty's fear of what has, for a long time, kept Your Majesty from implementing these five desirables?”陛下誰憚而久不為此五美? While leaving the sentence intact, Lu Wenchao put the following note immediately beneath the sentence: "The last two graphs [i.e. “五美”, meaning “five desirables”] must be a title of the pre-

\footnotetext{
${ }^{15}$ In addition to these titles, there are also two end titles for individual treatises which modern archaeologists were able to identify only after they had soaked the bamboo texts in water for a long time (see Shuihudi Qinmu zhujian, 1978: p. 2, footnote 1).

${ }^{16}$ Yet, sometimes some basic training in archaeology and Chinese textual criticism is required for one to be able to identify the titles. Otherwise, one could be under an erroneous impression that the use of titles in the currently available Qin and Han scripts was very rare and exceptional. In the case of Shuihudi texts, for example, there were two end titles which modern archaeologists were able to discern only after they had soaked the bamboo texts in water for some time (Shuihudi Qinmu Zhujian, 1978: p. 2) It should be noted that the quantity of identified end titles in the Shuihudi scripts is significantly above the level of being rare and exceptional. The occurrences of end titles in the Mawangdui texts are also evident. There is, for instance, a title "at the end of each essay in the [Mawangdui silk] manuscripts" that Yates translates in his book. I concur with Yates that the use of such end titles "is not the practice of early and middle Warring States texts" but one that "starts to appear in the third century B.C.E." (Yates, 1997: p. 197) Besides their occurrences in excavated scripts, residues of end titles can also be found in some post-Han editions of Han compilations of early texts, such as the Xunzi and the Lüshi chunqiu (see also Yates, pp. 197-198; Zhang Shunhui, 1990: p 184).

${ }^{17}$ According to Zhang Xuecheng 章學誠 (1738-1801) (1985: p. 395), chapters of ancient texts usually remained untitled. Professor Zhang Shunhui (1990: p. 184) also pointed out that the chapter titles of most pre-Qin texts were posterior impositions. One may thus deduce that the same holds true for passage titles.
}

ceding passage”末二字當目上文. In Lu’s judgment, therefore, the two graphs 五美 at the very end were originally meant to be a title rather than part of the last sentence of the passage. Hence according to Lu's reading, the last sentence should be: "Your Majesty's fear of what has, for a long time, kept Your Majesty from implementing this?” 陛下誰憚而久不為此?

The extant Xinshu, as is indicated in our Introduction, can be traced back to some Song editions that eventually survived in Lu Wenchao's edition and Lu's notes therein. It can be inferred from Lu's note that the last two graphs, "wumei," had already been treated as part of the main-body text in the Song editions that $\mathrm{Lu}$ witnessed. Yet the sentence, just by itself, would be grammatically and idiomatically correct regardless whether this disyllabic word were added or not. Besides, in Lu Wenchao's edition, the same two graphs were also used in the beginning of the passage as a chapter title. Difference in opinion has thus occurred regarding where this disyllabic word belonged.

In the past, there have been modern annotators who exemplified the difference in their annotated editions of the Xinshu. In their 1989 edition, Wu Yun and Li Chuntai mixed the disyllabic word into the main-body text. Wang Zhouming and Xu Chao (1996: p. 62), in contrast, dropped the disyllabic word and then added an editorial note, declaring that they had done so in accordance with two editions in the Ming dynasty as well as the quote of the text in Hanshu 48 (i.e. biography of Jia Yi). Fang Xiangdong (2000, p. 89) quoted Lu Wenchao's note without a comment. The same year, Yan Zhenyi and Zhong Xia (2000: p. 70) remarked in their annotated edition of the Xinshu that since there were no other occurrences of end titles in the extant Xin$s h u$, they judged these two graphs to be redundant graphs rather than an embedded end title.

In this particular case, I suggest basing our judgment primarily on the text itself instead of on either the Hanshu or any postSong editions of the Xinshu. Although neither the presence nor the absence of the two graphs would result in a grammatically incorrect sentence, a scrutiny of the text will lead us to the conclusion that only the absence of those graphs is contextually appropriate.

This passage was composed to advise the emperor to institute a system of dizhi 地制 (enfeoffment). Instituting the system would, as the author argued, make the emperor's virtue known to the "sub-celestial world" in five aspects. Thus the "five desirables" refer to the world's five kinds of recognition of the emperor's virtue. Apparently, one can securely infer from this argument that all the emperor was capable of was having the five desirables "done" to his majesty himself. In other words, the five desirables were not something that the emperor was able to initiate directly. They were, rather, the five rewards for the emperor to earn, the five things that the "sub-celestial world" would do to his majesty as a response to and reward for his successful establishment of that system. The object of the verb “為”, therefore, has to be the enfeoffment system, not the "five desirables". And the pronoun “此”- - meaning "this" - should be taken as a singular demonstrative pronoun that denotes the system of enfeoffment. Lu Wenchao is, therefore, correct in considering the last two graphs external to the last sentence.

As for whether the two graphs merely remain as a redundant word or function as a title, there can be no definitive answer. But there is no mutual cancelling between the two possibilities. It was likely that the two graphs, "wumei”, remain in the text as 
both a redundant word and an embedded end title.

There were, to recall, pre-modern scholars and book compilers who mistook embedded end titles for part of the main-body text. There were also editors who would, by mistake or on purpose, change former print-formats (Gu Yanwu, 1990: pp. 908909; Zhang Shunhui, 1962: p. 35; Zhu Taiyan, 1989: p. 47). The Song editions of the Xinshu, though extant no more, had remained to be "the sole sources for all later editions" in the form of Lu Wenchao's commentaries on them (Svarverud, 1998: p. 24). Cherniack observes that the Song dynasty was a time when Chinese book culture favored change. Consequently, "the supports that had earlier served to stabilize the texts were weakened, and canonical texts, like other texts, became open to textual innovation" (Cherniack, 1994: p. 21). Her comment is in agreement with Zhu Taiyan's (1989: p. 47) description of the fashion during the Song dynasty among reproducers of ancient books.

Because the use of embedded end titles was popular in the Han era and the modification of early formats was a common practice during the Song times, it stands to reason to suspect that there were originally other end titles in the Xinshu. But a thorough removal of them would require both knowledge about early formats and the ability to recognize such titles. In the Xinshu, other end titles could be easily detected because it was grammatically or idiomatically impossible to merge the titles into the sentences that they individually followed. But the presence of the embedded title "wumei" does not make its preceding sentence any less idiomatic than does its absence. The title hence survived deliberate removals and remained as redundant graphs in the text. Chen Weiliang discusses textual corruption from the primary perspective of falsification. But passage title is an important factor to consider in this matter.

\section{The Siku Tiyao and Yao Nai}

To discredit a historical document normally means to find it anachronistic. As late as the Qing Dynasty, compilers of the Siku Tiyao and-especially-Yao Nai both claimed to have found concrete evidence of forgery in the Xinshu.

\section{The Siku Tiyao}

In their discussion of the Xinshu, the Siku compilers remarked that "the book is not entirely authentic, nor is it entirely forged” 其書不全真, 亦不全譌 (Siku quanshu zongmu tiyao, juan 49). The evidence of its not being "entirely authentic," they declared, lied in the corrupted condition of the text and the titles that seemed to have been artificially imposed on passages (Ibid). These are the topics that we discussed in the previous section. The reason they considered the Xinshu not "entirely forged" was because they found that, among the parts of the Xinshu with no textual parallels in the Hanshu, there were texts rich in early teachings with their sources traceable in ancient classics. The compilers thus differ from many modern skeptics of the Xinshu in that they were not unwilling to give credit to the parts of the Xinshu that lacked textual parallels in the Hanshu, though the compilers' judgment in this regard is rather subjective.

\section{Yao Nai}

Yao Nai's skepticism, by contrast, was directed to the entire
Xinshu. He considered the Xinshu questionable in textual and historical aspects. In the textual aspect, the grounds of his skepticism do not differ significantly from those of other skeptics discussed in our previous sections. But his criticism in historical aspect deserves our particular attention.

In the "Dengqi" 等齊 Chapter of the Xinshu, the author said he would "sigh over" the practice of using gold seals among the ministers of enfeoffed lords. Yao Nai considered the "sighing" as an anachronistic react to what had already come to be normal by Jia Yi's time, when lords began to lose interest in honoring codes of protocols appropriate to their individual statuses and ranks. What is more, in the chapter of "Dengqi," enfeoffed lords are addressed as bixia 陛下. And the term fei 妃 (concubine) is found to be an alternative title for hou 后 (queen). Yao Nai argued that, firstly, bixia was a title that no lords in the Han era could possibly adopt because the titled had been allocated for the emperor alone in the Qin Dynasty. Secondly, to refer to a queen as a fei was a practice that did not occur in history until as late as the Wei-Jin period. So, its occurrence in the "Dengqi" Chapter seemed to suggest that the Xinshu was forged in or after the Wei-Jin times.

As regards the use of the title bixia, Wang Zhouming points out that the purpose of the chapter was to denounce the practice of addressing a lord as bixia (Wang Zhouming, 1982: p. 12). The chapter was, in other words, taking issue with the lords' disregard of protocol codes. As for referring to a queen as $f e i$, it should be noted that the original meaning of $f e i$ is "spouse", not "concubine” (Zhang Shunhui, 1983: juan 24, p. 5b). And according to Wang Zhouming (1982: p. 21), the character 妃 in this sense is pronounced pei instead of fei. Therefore, the sentence “Tianzi zhi pei hao yue hou” 天子之妃號曰后 in "Dengqi" simply means "the spouse of the Son of Heaven is known as a Queen”.

Moreover, Yao Nai's criticism of the chapter regarding the "sighing over" the use of gold seal may instantly remind us of what Wang Guowei 王國維 (1877-1927) found about the "Dengqi” Chapter. The chapter mentions some official titles in the courts of enffeoffed states. Wang Guowei had once judged those titles to be particular only to the governance structure of the central court. For this reason, he had long considered this chapter untrustworthy until one day he witnessed a number of clay seals that had been in use during the Han Dynasty in the court of an enffeoffed state. Right on the seals, Wang noticed precisely those titles that he had found in the "Dengqi" chapter. Wang said he then realized that what was said in "Dengqi" was true: It was true that enffeoffed lords during the Western Han had lost interest in protocol codes and begun emulating the emperor in the system of officialdom (Wang Guowei, 1973: juan 18, p. 921).

But if this was a common practice among the lords, does it mean Yao Nai was right in pointing out the "sighing" in the "Dengqi" Chapter to be an anachronistic reaction to it? The key issue here, I think, is not what practice was common and normal in that period, but rather what practice would look intolerable to the author of the chapter no matter how common, normal, or even fashionable the practice might have been in his time. It was all a subjective matter on the part of the author. A historical and objective perspective would thus be totally irrelevant.

\section{Chen Weiliang's Criticism Reviewed}

As a scholar in modern time, Chen Weiliang (1958) epito- 
mizes all skepticism of the Xinshu and contributes to significantly deepening our study. His criticism-which examines the Xinshu from literary, historical, and philosophical perspectives (Nylan, 1992: p. 169)—strikes as more comprehensive and sophisticated than that of all his predecessors. Critics of the Xinshu today can hardly afford to ignore his study. Nylan (1992) and, especially, Svarverud (1998) have both presented in-depth reviews that did justice to Chen's contributions. My review below will discuss Chen's criticism on the minben 民本 thought and what one may call senary-composite cosmology in the $X i n s h u$. In addition, I will discuss his arguments on the stylistic issues in the Xinshu and how the Xinshu was related to other texts, especially to the Shuoyuan 說苑 and Zuozhuan 左傳.

\section{Five or Six}

In the Xinshu, both the "Liushu” 六術 and "Daode shuo" 道德說 chapters argue that everything in the universe is six-fold. According to Hanshu 48, however, Jia Yi suggestedover 20 years after the founding of the Han Dynasty-that the Han Empire establish yellow as the most important color, change the calendar of his time, and replace the quinary customary and ritual system with a senary system, in which, for example, physical dimensions of utensils were to be set at six lengths (i.e. chi 尺 and/or cun 寸) and the emperor would use a six-horse chariot. Chen Weiliang (1958: p. 27) considered such discrepancy between those chapters and Hanshu 48 suggestive of a case of textual forgery on the part of the Xinshu.

The discrepancy is admittedly obvious. But I do not think it substantiates an assumption of Jia Yi's consistent insistence upon the implementation of a quinary system. Viewed from a perspective of Five-Phase 五行 theory in pre-modern China ${ }^{18}$, succession of dynastic regimes would follow a cycle of destruction 相剋 in the sequence of Wood-Soil-Water-Fire-MetalWood. The founding father of the Han Dynasty, Emperor Gaozu (r. 206-195 BC), initially considered himself an agent of Fire. Before long, he was convinced that his regime represented the element of Water, whose corresponding numbers were, to note, both One and Six. Later, during the reign of Emperor Wen (r. 179-157 BC), Jia Yi and Gongsun Chen 公孫臣 (fl. 165 BC) successively petitioned to have Soil recognized as the dynastic element and to honor both its color yellow and its corresponding number Five (Hanshu, p. 1270) ${ }^{19}$. But it was not until about 60 years later that the Han Empire adopted the institutions they had suggested (Ibid, pp. 199-200).

Thus we know, the early period of the Western Han era underwent a transition from upholding Water to upholding Soil. The transition overlapped with Jia Yi's lifetime and coincided with the discrepancy that Chen Weiliang discovered.

In response to Chen Weiliang's argument, Svarverud (1998: pp. 129-134) has made a cogent point from the perspective of Chinese intellectual history. He finds that numbers Five and Six

\footnotetext{
${ }^{18}$ Readers who do not read Chinese please consult Needham, et al. (19541999: Vol. 5, part 3) for a detailed account of the Five-Phase theory in early China.

${ }^{19}$ Without documenting his point, Chen Zhi 陳直 (1901-1980) (1979: p. 288) maintains that the quinary system that Jia Yi proposed applied only to the number of characters in the official titles inscribed on the official seals. By that, he means that Jia Yi suggested using five-character official seals to replace their contemporary four-character seals. Chen Zhi also points out that the five-character seals that Jia Yi suggested were not in use until Emperor Wu's reign. I have found evidence indicating Emperor Wu's adoption of five-character seals in the Shiji (p. 1402) and Hanshu (p. 1245).
}

had been, by Jia Yi's time, well integrated in early Chinese philosophical and political thoughts, with the former number "corresponding to the Five Elements, or Phase, in cosmos" and the latter "as the Heavenly number describing the cosmic origin of things” (Svarverud, 1998: p. 132). And he further contends that Chen Weiliang's “interpretation of an opposition between the cosmological significance of five and six as evidence for the non-reliability of these chapters in Xinshu is superficially argued,” because

There is ample evidence for a cosmology interpreting Heaven as containing the essential six $q i$ [氣] which in turn give birth to different qualities in the world of things, not [Svarverud's italic] excluding but rather forming a comprehensive cosmology incorporating the historical cyclicity of the Five Elements in early Han cosmology. Based on pre-Han and early Han cosmology the scheme of all things origination in a six-fold division presented in the chapters Liushu and Daodeshuo seems, on the contrary, to conform to expectations with regard to the writings of the Han eclectic Jia Yi (Svarverud, 1998: p. 133).

Svarverud's point is argued through ample citations of early sources. To the list of his examples, I would add the Guoyu 國 語, where the following cosmological theorization is found:

The Heaven is six-fold whereas the Earth five-fold. Such are the numeric constants [in the cosmos]. The heavenly [sextuple] function as longitudes while the earthly [quintuple] as latitudes. The longitudes and latitudes [interweave] with no error, hence the [formation of cosmic] pattern. 天六地五, 數之常也。經之以天, 緯之以地, 經緯不爽, 文之象也 (Guoyu, 1978: juan 3, p. 98).

Wei Zhao’s 韋昭 (204-273) annotation elaborated on this notion of cosmic pattern and substantiated the concepts of sextuple and quintuple with the following remark.

In the heaven there are six qi, namely yin, yang, wind, rain, darkness, and brightness. On earth there are five elements. [They are] Metal, Wood, Water, Fire, and Soil. With the six heavenly qi functioning as longitudes while the five earthly elements as latitudes, [the cosmos] is complete. 天有六氣, 謂陰、陽、風、雨、晦、明也。 地有五行: 金、木、水、火、土也。以天之六氣為經, 以地之五行為緯, 而成之也 (Guoyu, 1978: juan 3, p. 98).

Evidently, this passage in the Guoyu confirms Svarverud's point that numbers Six and Five were integrated in early Chinese cosmology.

\section{The Minben 民本 Thought}

In such Xinshu chapters as “Dazheng No. 1” 大政上 and “Dazheng No. 2" 大政下, Chen Weiliang identified “the political thought of treating-people-as-basis”民本政治思想. After comparing the themes of these two chapters with that in Jia Yi's quotes in the Hanshu, he judged the two chapters to be artificial early writings. Central to this observation is apparently his assumption that things absent in authorized dynastic histories are unreliable. In terms of the minben thought, however, the present study does not find the two Xinshu chapters inconsistent with the “Guo Qin lun” quoted in the Shiji 史記, which 
was no less established as standard history than was the Hanshu. Besides, I do not think that there was only one kind of minben thought in early China.

The term minben is arguably a short form for the phrase " $\min$ wei bang ben” 民惟邦本 (common populace is the foundation of the state) in Chapter “Wuzi zhi ge” 五子之歌 in the oldtext Shangshu 尚書. According to the chronology suggested by Yan Ruoqu 閻若璩 (1636-1704) (1796), the old-text Shangshu may not have predated Jia Yi's time. But the "minben thought" is nevertheless a convenient posterior label for the kind of early persuasions that accorded importance to the common populace. Mencius (7B: 14) is widely quoted to have said "(in a state) the people are the most important; the spirits of the land and grain (guardians of territory are the next; the ruler is of slight importance" (Chan, 1963: p. 81). One would agree with Chen Weiliang on the marked difference between this type of minben thought and that conveyed in those two Xinshu chapters.

Chen Weiliang's (1958, p. 27) observation on the "spirit of Legalism” (fajia jingshen 法家精神) in Jia Yi's thought is well founded. With very few exceptions (e.g. Yang Shuda, 1984: Vol. 7, p. 479), scholars generally agree with Ban Gu that Jia $\mathrm{Yi}$ "was well versed in (the thoughts of) Shen (Buhai) and Han (Fei)” 明申韓 (Hanshu, p. 2723). Scholars in the Song Dynasty paid particular attention to this aspect of Jia Yi. Ye Shi 葉 適 (1150-1223) once remarked that Jia Yi's Warring-State type of strategies was adorned in his use of Confucian principles (see Qian Zhongshu, 1979: p. 893). Chen Liang 陳亮 (11431194) (1987: pp. 126-128) regarded the "heterodox learning" 異端之學 of Legalism as an important complement to the Confucianism in Jia Yi's thought. In Northern Song times, Su Shi 蘇軾 (1986: Vol. 1, p. 315) took for granted Chao Cuo’s 昆錯 (200-154 BC) “heretical ideas” of Legalism but felt surprised at the same ideas manifested in Jia Yi's teaching. To Wang Fuzhi 王夫之 (1619-1692) (1996: Vol. 10, p. 104) in the Ming-Qing period, Jia Yi “sounded scarcely different from Li Si” 去李斯之言也無幾.

Given all these attestations, one would still expect Chen Wailiang to explain why he had considered the minben thought and the "spirit of Legalism" mutually exclusive. In Chapter 23 of the Guangzi 管子, it is said "[a] hegemonic or kingly dominance would start from treating the common populace as a foundation. The state will be stable [so long as] the foundation is in order. [Should] the foundation become chaotic, the state would be in jeopardy.” 夫霸王之所始也以民為本, 本治則國 固, 本亂則國危 ${ }^{20}$. Further reading of the chapter will take us to a focused discussion on how to accomplish dominance and ensure the triumph of one's state in wars of annexation. Such a topic is of course more pertinent to the will of a ruler than it would be for the interest of the common populace. This obviously speaks of a certain convergence between Mencian minben thought and Legalism.

Early Legalist thinkers lacked the chance to examine enough of the formindable force of nationwide mass riots, such as the

\footnotetext{
${ }^{20}$ In the received edition of the Guanzi, the first sentence reads “夫霸王之所 始也以人為本.” According to Yan Changyao’s 顏昌嶢 (1868-1944) (1996: p. 214, p. 219) annotation, the extant edition of the Guanzi dates back to the Tang Dynasty, when the graph “人” was supposed to be used in place of “民” in order to avoid the taboo name of Li Shimin 李世民, Emperor Taizong of the Tang Dynasty. I therefore restored the graph “民” in my citation of the Guanzi here.
}

untouchable's general uprisings by the untouchables towards the end of the Qin Dynasty ${ }^{21}$. They therefore variously emphasized what Mark E. Lewis calls "sanctioned violence" as their answer to all socio-political situations ${ }^{22}$. Around the fall of the Qin Empire, early-Han literati found in sanctioned violence something that might arouse vehement reaction from the masses. Such awareness was amply reflected in the political discourse of the early Han period, including the speeches of Jia Yi. In this regard, the minben thought detected by Chen Weiliang in the Xinshu does not seem to significantly deviate from Jia Yi's Legalist inclinations reflected in the Hanshu. I choose to refer this kind of minben thought as practical minben thought.

It is said in Chapter "Dazheng No. 1" that a ruler "cannot afford not to fear the people” 民不可不畏也. This presumably comes from the "Jiugao" 酒誥 chapter of the Shangshu, where King Cheng of Zhou said that "previously, the sage king of the Yin held [both] the Heavenly Sovereignty [and] petty commoners in awe” 在昔殷先哲王迪畏天顯小民. Thus, insofar as they were the object of the sage king's fear, "petty commoners" were considered second only to the "Heavenly Sovereignty." The Xinshu chapter elaborates on this idea of fearing the people, cautioning that a ruler, "therefore, cannot slight even the most base, nor deceive even the most foolish, commoner among general populace,” 故夫民者, 至賤不可簡也; 至愚不可欺也 because, "from ancient times to now, [it has always been the case that] he who sets himself against the people will be sooner or later overcome by the people”. 故自古至於今, 與民為倠 者, 有遲有速, 而民必勝之. In the same chapter, a ruler's regime is said to be doomed once people loathed what the ruler wanted them to do. Likewise, in the Shiji, we catch Jia Yi arguing eloquently in his "Guo Qin lun" that, upon the loss of people's favor, the Qin Empire-a formerly invincible conqueror of six well armed states - could not even withstand the strike from a crowd of untouchables who were armed with only wood clubs and hoes. This kind of reasoning found in an orthodox history is by no means incompatible or inconsistent with the practical minben thought conveyed in the two Xinshu chapters.

\section{Stylistic Issues}

As is summarized in the Introduction, in late 1950s and early 1960s respectively, Chen Weiliang in Hong Kong and a team of four scholars in Beijing compared the texts of the Xinshu and that of Jia Yi’s quotes in the Hanshu. After comparing almost

\footnotetext{
${ }^{21}$ But, even in that early period, Xunzi 荀子 (4th-3rd cent. BC), the alleged mentor of such major Legalist theorists as Han Fei 韓非 and Li Si 李斯, was already aware that the masses were to the ruler what water was to boat. By that he meant that, just as water was capable of both carrying and overturning a boat, so were the masses capable of upholding and overthrowing their ruler (see Xunzi, 1936: Vol. 20, p. 100). In the Liji 禮記, incidentally, it is also argued that a gentlemen cannot afford to overlook the general populace any more than one can afford to overlook water, which is capable of taking human life if one is careless about it (Liji, 1983: Vol. 116, 412b). Like the thought of Xunzi, the Laozi 老子 was also a rich source of influence to Legalism. Argument similar to the forgoing, for instance can also be found in Chapter 39 of the Laozi.

${ }^{22}$ According to Lewis, sanctioned violence was "modes of inflicting harm or taking life which men accept, approve, and even prescribe.” By that he specifically refers to the imposition of the will of the ruling upon the ruled, or that of one state's will upon another, through institutionalized use of force (Lewis, 1990: p. 1).
} 
the same set of texts, Chen Weiliang and the team of four scholars has each reached an opposite conclusion to the other's argument. Whereas Chen Weiliang contended that the quotes of Jia Yi in the Hanshu presented a smoother reading than did the $X i n s h u^{23}$, the four scholars judged the latter to be smoother in reading than the former. Obviously, different scholars' personal tastes for writing styles were at play in their textual criticism.

If Zhang Xuecheng's 章學誠 (1738-1801) observation can be accepted, we must take into account that there were times when pre-modern historians edited and revised the historical documents they quoted ${ }^{24}$ (Zhang Xuecheng, 1956: p. 65).

And one would question the assumption Chen Weiliang and the four scholars shared despite their difference. It is an assumption that idealizes Jia Yi's writing style. Based on this shared assumption, Chen and the four scholars in fact agree that, between the Xinshu and Jia Yi's quotes in the Hanshu, a better-written text must be the original text. Chen Weiliang particularly shows an inclination to idealize Jia Yi's writing. He, for example, considered the "Daoshu” 道術 chapter unauthentic because he found part of the essay "long-winded, meaningless, continuously garrulous, [and hence] unlikely to be what an ambitious and patriotic Jia Yi would have cared to say.” 穴長 無義, 絮絮不休, 似非胸懷大志, 存心家國如賈誼者所屑 言也 (Chen Weiliang, 1958: p. 26). As a similar example, his comment on two other Xinshu chapters is: "As a writer with a natural and flowing style, Jia Yi could never have possibly written such self-repetitive and awkward sentences. Such is the shallowness and vulgarity of the forger.”文章疏宕如賈誼者 亦決不會為此重複笨拙之句, 此乃偽者之淺婳 (Ibid, p. 28). In both cases, Chen Weiliang (1958: pp. 4-5, 26-27) considered the textual and stylistic problems suggestive of a forger whose writing skill was markedly inferior to that of Jia Yi.

Svarverud (1998: p. 81) rightly imputed some of the repeated passages to the physical damage of the bamboo texts. Regarding those problems that are more stylistic than physical in nature, one would wonder whether a stylistically imperfect text is necessarily a forged text. I choose to answer the question through a discussion on critics' reception of the first part of Jia Yi’s “Guo Qin lun” (i.e. “Guo Qin lun No. 1”).

Although textual scholars disagree about the authorship of the Xinshu, they all regard "Guo Qin lun No. 1" as an authentic. Chen Weiliang largely relied on "Guo Qin lun No. 1" in his discussion of Jia Yi's thought. As a text with a clear line of transmission, "Guo Qin lun No. 1" is quoted in full in the Shiji. From there, according to Svarverud (1998: p. 48), Ban Gu quoted it in his Hanshu. Later on, it was included in numerous prestigious anthologies, of which Xiao Tong’s 蕭統 (501-531) Wenxuan 文選, Yao Nai's Guwen Cilei Zuan 古文辭類纂, and Yan Kejun's 嚴可均 (1762-1843) Quan Shanggu Sandai Qin Han Sanguo Liuchao Wen 全上古三代秦漢三國六朝文 are only a few examples.

\footnotetext{
${ }^{23}$ Likewise, Yao Nai in pre-modern China considered the Xinshu spurious partly because, to him, the Xinshu texts did not read as smoothly as their textual counterparts in the Hanshu.

${ }^{24}$ In the Hanshu, we see a long quote of Jia Yi's petition that is capped by Ban Gu's introduction to it. The introduction declares that this long quote only “roughly” [dalue 大略] presents Jia Yi's petition. As a pre-modern annotator of the Hanshu, Yan Shigu 颜师古 noted that this was “probably [a case where] the historian simply put [in the history] what was important and relevant". "And," said Yan Shigu, "[that is why Ban Gu] later said in the final comment that [he] 'selectively' included in [Jia Yi's biography] those [essays] that were pertinent to the affairs of that time.”蓋史家直取其要切 耳。故下贊云掇其切於世事者著於傳 (Hanshu, p. 2260).
}

Yet “Guo Qin lun No. 1” has not always been favorably received among critics. Scholars normally appreciate its vigorous style. But they notice that it is a text that features sentences "too [lengthy] to recite or read aloud” 難於諷誦 (Huang Kan, 1962: pp. 145-146), redundant expressions, "unsymmetrical and unstable parallelism” 對偶偏枯机叟, “piled-up phrases” 堆疊成 句, and "lavishness in words in excess of substantiality in meaning” 詞肥義瘦 (Qian Zhongshu, 1979: p. 891). Could it possibly be coincident that Chen Weiliang found in those Xinshu chapters exactly the same kind of stylistic problems as those other modern scholars found in "Guo Qin lun No. 1?”

In fact, there were also pre-modern scholars under the same impression about Jia Yi's writing. Zhu Xi 朱喜 (1130-1200), for one, caught Jia Yi "scribbling haphazardly all along on the wings of [his] talent”. 只是乘才快, 胡亂寫去 (see Qian Zhongshu, 1979: p. 888). His remark echoes an earlier remark by Su Shi, who found Jia Yi "opulent in talent while inadequate in insights”. 才有餘而識不足 (Su Shi, 1986: Vol. 2, p. 777).

Chen Weiliang has certainly demonstrated incisive discernment in identifying Jia Yi's stylistic flaws. But let us not forget that such flaws are shared by the texts that Chen considers unreliable and those that he trusts with no reservations.

\section{The Xinshu vs. Other Early Texts}

Chen Weiliang has also taken note of some textual similarities between the Xinshu and three other texts ${ }^{25}$. He found the texts in the Xinshu shorter than their textual counterparts in those three books, and thus suspected the Xinshu of being partly forged on the basis of those books because, had those three books quoted the Xinshu, their texts would have been either of same length as, or shorter than, the Xinshu texts ${ }^{26}$.

However, among the three textual parallels between "Xiuzheng yu No. 1” 修政語上 (Xinshu) and “Jundao” 君道 (Shuoyuan), I find only one case in which the Xinshu text is shorter. Svarverud must have noticed this as well. He observes that Chen Wailiang has based his "argument on a limited number of passages among all the parallel passages in these texts" (Svarverud, 1998: p. 62).

As a matter of fact, to say that, between the two sources, the longer text is the original text, we have to eliminate one more possibility suggested by the four scholars in Peking University. It is the possibility that both the Xinshu and non-Xinshu texts were quoting an unidentified third source instead of each other (see Sun Qinshan et al., 1961: p. 65). This is a possibility that one can never rule out. But since the third source is still hardly identifiable, and considering the large quantities of early texts lost to time, let us base the discussion solely on what is known.

In the following, I will compare two texts between which the $X i n s h u$ and non-Xinshu texts are equally readable but of significantly different lengths. The point I wish to make is that, even if we, for the sake of argument, rule out the possibility of there being a third source, forgery on the part of the Xinshu is still not the best explanation for a text parallel. Now let us examine the example below, where the Shuoyuan passage is significantly longer than its counterpart in the Xinshu.

\footnotetext{
${ }^{25}$ They are Dong Zhongshu’s 董仲舒 (198-106 BC) Chunqiu Fanlu 春秋 繁露 and Xiu Xinag's Shuoyuan 说苑 and Хinxu 新序.

${ }^{26}$ The examples he cites are, specifically, “Rongjing” 容經 (in the Xinshu) vs. “Yubei” 玉杯 (in the Chunqiu Fanlu), “Chunqiu” 春秋 (in the Xinshu) vs. “Zaishi No. 4" 雜事四 (in the Xinxu), and “Xiuzheng yu No. 1" 修政 語上 (in the Xinshu) vs. “Jundao” 君道 (in the Shuoyuan).
} 


\begin{tabular}{|c|c|c|}
\hline Source & “Xiuzheng yu No. 1 (Xinshu) & “Jundao” (Shuoyuan) \\
\hline Text & 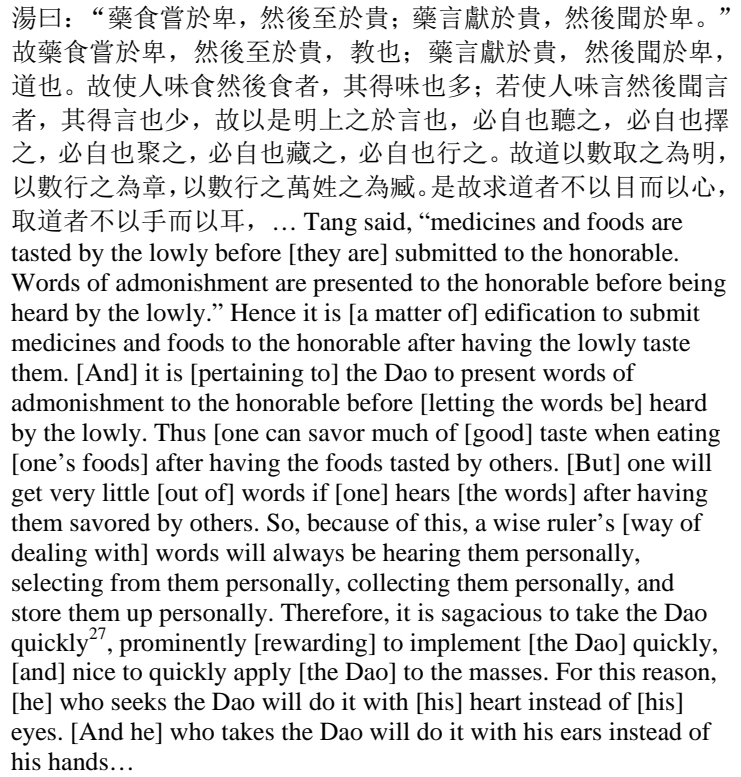 & 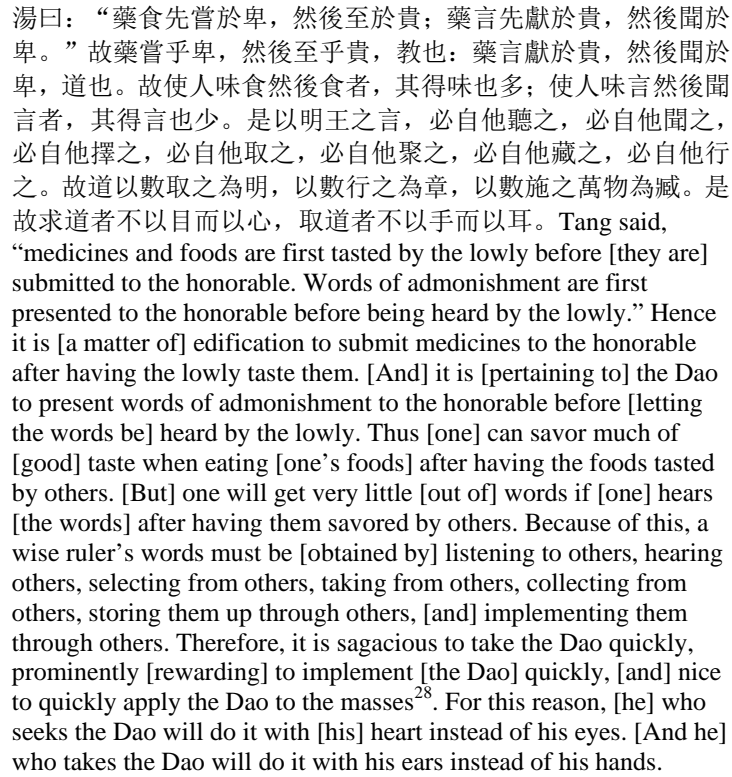 \\
\hline
\end{tabular}

Between these passages, the Shuoyuan passage obviously owes its more extensive length to its longer sequence of “必自 X Verb 之” structure. To me, the “也” in the former's “必自也 Verb 之”makes better sense than the latter's “他”, because what the entire passage says is that since one gets "very little [out of] words if [one] hears [them] after having them savored by others", a "wise ruler" should "personally" deal with and work on what is advised to him rather than do it through others. So, the “自” in the structure is more likely to be an adverb [meaning "by oneself"] than a preposition [meaning "from" or "through"]. Thus, in spite of the longer text on the part of a non-Xinshu source, the comparison above does not support the view that the Xinshu was quoting the Shuoyuan. If one had to explain their different lengths in terms of one source's quoting another, then we should say this looked rather like a case in which the author of the Shuoyuan had been elaborating on a passage that he saw in the Xinshu.

Inter-textual relation in early literature is a complicated matter. In pre-modern times, there was not a definitive demarcation drawn between quoting and paraphrasing. Just as Wang Mao 王杛 (1151-1213) observes, “[there have been cases where] the ancients did not present verbatim quotes of classics and early philosophies. [They] often added and omitted [words] at will.” 古人引用經子語, 不純用其言, 往往隨意增減 (Wang Mao, 1939: p. 117) ${ }^{29}$.

Besides, by the Han Dynasty, although manual transcription had long been an important means of preserving texts, the tradition of oral transmission did not extinct (Zhang Shunhui, 1990: p. 5) Both oral and manual transmissions were liable to generate different versions of a text. Gardner once enumerated several cases in which rival versions might occur (Gardner, 1961: pp. 48-52). Thus nothing can guarantee an extant text to be the only version there has been in history.

\footnotetext{
${ }^{27}$ Read 數 as 速.

${ }^{28}$ Read 藏 as 藏.

${ }^{29}$ Zhu Guozhen 朱國楨 (?-1632) must have also noticed this. See his Yong

Zhuang xiaopin 湧幢小品, juan 18.
}

Finally, as indicated above, there have been large quantities of early texts lost to time. Of the 29 quotes of Confucius in the Mencius, only eight have had their sources identified. But few of the eight quotes present perfect textual parallel to their sources (Gu Yanwu, 1990: p. 339). Considering all this, it is hardly feasible or constructive to compare lengths in search of an authentic text.

\section{The Xinshu and the Zuozhuan}

From Hanshu 88, we learn that Jia Yi was the leading scholar of the Zuozhuan study in his generation. In his time, he studied, taught, and wrote about, the Zuozhuan. His expertise in the study of the Zuozhuan is confirmed in Wu Chengshi's 吳承 仕 (1885-1939) Jingdian shiwen xulu shuzheng 經典釋文序 錄疏證 (1984: p. 123). However, Wang Zhong 汪中 (17441794) (1869: neipian 3, p. 5) noticed that, in those parts where history of the Spring-Autumn period was cited and discussed, the Xinshu did not present sufficient textual parallels to the Zuoahuan. In other words, the author of the Xinshu did not demonstrate enough of his familiarity with the Zuozhuan.

Liu Fenglu 劉逢祿 (1776-1829) (1995: p. 254a) also considered the connection between the Xinshu and the Zuozhuan weak. From there, he proceeded to question the conventionally alleged authorship of the Zuozhuan. From the late 19th to the beginning of the 20th centuries, however, Liu's judgment encountered vigorous challenge. Zhang Binglin 章炳麟 (18681936) refuted Liu Fenglu's view on several occasions. In his Chunqiu Zuozhuan xulu 春秋左傳敘錄, Zhang Binglin exhibited numerous examples to argue that the Chunqiu (i.e. Spring-Autumn Period, 770-467 BC) lore in the Xinshu did not contradict but rather complement the Zuozhuan ${ }^{30}$ (e.g. Zhang Binglin, 1982: Vol. 2, pp. 841-843). Similarly, Yu Jiaxi also

\footnotetext{
${ }^{30}$ In a speech he delivered in his old age, Zhang Binglin noted in passing that the Xinshu "abounded in the citation of Master Zuo (Qiuming)" (Zhang Binglin, 1995: p. 121). See also his Liu Zizheng Zuo Shi Shuo 劉子政左氏 說.
} 
remarked that, in the Xinshu, Chapter “Baofu” 保傅 was partly based upon the Zuozhuan (Yu Jiaxi, 1963: pp. 266-267).

But the view of Wang Zhong and Liu Fenglu seems nevertheless valid. Usually, without annotators' aid, (e.g. Yang Shuda, 1984: Vol. 10, p. 751; Yang Bojun, 1981: pp. 719, 788789, 1195) the parallels between the Zuozhuan and the Xinshu would easily pass unnoticed, for they are mostly imperfect parallels. Among all the 12 citations of the Zuozhuan recorded in The Xinshu with parallel passages from other pre-Han and Han texts, wording parallels are sporadic and rare ${ }^{31}$. More surprisingly, the title of Zuozhuan is simply not mentioned in the Xinshu. What first-class expert would demonstrate so little knowledge in his acclaimed area of expertise?

There has been, to my knowledge, no one in China-at least no one in the Chinese mainland-that has attempted to answer this question. In Europe, Svarverud has suggested two answers, between which, the first one is forthright. The lack of reference to the Zuozhuan is, as he suggests,

possibly an indication that Jia Yi was not [Svarverud's emphasis] well versed in the Zuozhuan, and may not even have composed the Zuozhuan commentary entitled Zuozhuan xungu 左傳訓故, as is recorded in Hanshu, Rulinzhuan 儒林傳 (Svarverud, 1998: p. 126).

Then why there is such a record in the Hanshu and Liu Xiang's 劉向 (77?-6? BC) Bielu 別錄 will become an unsettled issue. Compared with this first answer, Svarverud's second answer is more sophisticated. "Another more plausible explanation," says he,

seems to be that these historical events [of Spring-Autumn period] did not serve the intention of being historical records but rather moralistic anecdotes substantiating the lessons to be drawn from history. Jia Yi was thus less concerned with their historical accuracy and more concerned with their pedagogical effect on teaching in the state of Liang. As suggested by Wang Zhong these events may possibly also belong to a lost corpus of early orally transmitted texts not recorded in Zuozhuan (Svarverud, 1998: p. 126).

This is indeed an interesting point. Speaking of the records in the Zuozhuan, however, perhaps little matters how accurate they might be historically, many of them had already been rendered moralistic enough by their author to meet various pedagogic purposes. So, if Jia Yi did know them well, how did he find them unusable in his teachings? Why did he resort to anecdotes instead of the Zuozhuan? Here, Chen Weiliang's challenge is still not something we can afford to ignore. But if we review the transmission of the Zuozhuan, we will find that forgery is anything but the sole, or even the best, explanation for the lack of mention of the Zuozhuan in the Xinshu.

As Svarverud points out, Wang Zhong suspected that the events cited in the Xinshu were transmitted from texts other than the Zuozhuan. This suspicion might have been justified long ago in the 20th century. In the 1970s, a silk text of Spring-Au- tumn history entitled Chunqiu shiyu 春秋事語 was excavated in Changsha, Hunan Province ${ }^{32}$. Scholars agreed

\footnotetext{
${ }^{31}$ Cf. Ho Che Wah, et al., 2007, p. 41, p. 137 , p. 147 , p. 149 , p. 152 , p. 154 , p. 163 , p. 201, p. 220, p. 222, p. 223, p. 228.

${ }^{32}$ The original title of this text is unknown. The title Chunqiu shiyu was given by modern scholars after its excavation.
}

that the text was composed in the Warring States period and scribed around the founding of the Han Dynasty, between 210 and 190 BC (Zhang Zhenglang, 1977: pp. 36, 38). According to Zhang Zhenglang 張政烺, this is a text composed for pedagogic pur- poses, intended to prepare youths for further study of the Spring-Autumn annals (SAA henceforth). Without addressing an opposite opinion held by Tang Lan’s 唐蘭 ${ }^{33}$, Li Xueqin 李學勤 (1989: pp. 2-4, 6) substantiated Zhang Zhenglang's view by arguing that the Chunqiu shiyu was largely adapted from the Zuozhuan. While taking note of some differences between the two texts, Li Xueqin concluded that the Chunqiu shiyu was "indeed a categorical early work of Zuozhuan studies” 實為早期《左傳》學的正宗作品, particularly a work of Xunzi's tradition within the Zuozhuan school of historical studies. In- terestingly, while Wang Zhong noticed the significant discrep- ancy between a Spring-Autumn anecdote in the “Shenwei” 審微 chapter of the Xinshu and its counterpart in the Zuozhuan, Li Xueqin found the same anecdote in the Xinshu impressively parallel to its corresponding record in the Chunqiu shiyu. What this seems to suggest is that it is one thing not to directly cite the Zuozhuan, but it is quite another to deviate from the Zuo-zhuan school of SAA study.

The affinity between the Chunqiu shiyu and Zuozhuan is also noted by Wu Rongzeng 吳榮曾 (1998) and Wang $\mathrm{Li}$ 王莉 (2003) from different perspectives. And after comparing the style, syntax, narrative format, viewpoints, and chronology of events in this text and those in the Zuozhuan, Li Xueqin went on to tackle the significance of the title "Shenwei". He cited the following heritage line of the Zuozhuan school recorded in $\mathrm{Lu}$ Deming’s 陸德明 (556-627) Jingdian shiwen 經典釋文 and Liu Xiang's Bielu ${ }^{34}$ : Zuo Qiuming 左丘明—Zeng Shen 曾申 -Wu Qi 吳起-Wu Qi 吳期—Duo Jiao 鐸椒—Yu Qing 虞 卿—Xunzi-Zhang Cang 張蒼—Jia $\mathrm{Yi}^{35}$. Li Xueqin observed that, in the Zuozhuan school, there were four works that contained the character wei 微 in their titles ${ }^{36}$. And from $\mathrm{Li}$ Xueqin (1989: p. 5), we learn that Yan Shigu 顏師古 (581645) glossed the meaning of the wei to be "to explain the subtle

\footnotetext{
${ }^{33}$ Tang Lan's view was expressed on August 28, 1974, at a forum sponsored by the journal of Wenwu. A minute of the forum entitled "Zuotan Changsha Mawangdui Hanmu boshu” 座談長沙馬王堆漢墓帛書 is published in Wenwu 220.

${ }^{34}$ The heritage chain presented by Lu Deming 陸德明 ends with Jia Yi whereas that by Liu Xiang 劉向 ends with Zhang Cang 張蒼.

${ }^{35}$ Wang Zhouming (1982: p. 25) suggests that Jia Yi had another mentor called Master Wu 吳公. The heritage line Wang Zhouming presents is: Xunzi-Li Si 李斯—Master Wu—Jia Yi. I would assume that this is based upon the following account in Hanshu 48, "Jia Yi was a native of Luoyang. A [youth] of 18, he was well reputed in his prefecture for [his ability] to recite [and] interpret classics [and for his] literary talents. Master $\mathrm{Wu}$, Governor of Henan heard of his outstanding endowments. [He, thereupon,] summoned [Jia Yi and] placed [Jia] at his menxia. [Master $\mathrm{Wu}$ ] treated [Jia Yi] with exceeding favor [emphasis added] ... As formerly a townsman of $\mathrm{Li} \mathrm{Si}$, [Master Wu] once studied under [Li Si’s] mentorship.”賈誼,雒陽人 也, 年十八, 以能誦詩書屬文稱於郡中。河南守吳公聞其秀材, 召置門 下, 甚幸愛。……吳公]故與李斯同邑, 而嘗學事焉。It seems that Wang Zhouming associated the menxia 門下 with mensheng 門生 (disciple). But Chen Zhi 陳直 (1979: p. 288) pointed out that the term menxia here meant menfu zhi xia 門府之下 (official patronage). I choose to accept Chen Zhi's interpretation because I judge the phrase xing'ai 幸愛 to be not as an appropriate expression to describe mentorship as it is for describing patronage.

${ }^{36}$ Among the four, authors of the Zuozhi Wei 左氏微 and Zhangshi Wei 張 氏微 are unidentified but suspected to be, respectively, Zuo Qiuming and Zhang Cang (Li Xueqin, 1989: p. 5).
} 
meaning” 釋其微旨. Li Xueqin held that wei was a common genre in the Zuozhuan school of SAA study, which featured short discussions of the morals and lessons to be drawn from the Zuozhuan. He observed that works in this genre had sometimes used materials not included in the Zuozhuan. And, as a spin-off of his research, Li discovered that the style and format of Chapter "Shenwei" in the Xinshu were typical of this genre (Li Xueqin, 1989, pp. 5-6).

Moreover, Li found the excavation spot of the Chunqiu shiyu significant. As is generally known, Changsha was where Jia Yi once served as Grand Tutor for the King of Changsha. Considering his official post in Changsha and the fact that the Chunqiu shiyu was intended for pedagogical purposes, one may not feel very surprised at the similarity that Li Xueqin identified between the Chunqiu shiyu and "Shenwei".

Yet, we still have good reason to wonder why Jia Yi demonstrated so little of direct knowledge of the Zuozhuan. A remark by Wang Mao (1939: pp. 133-134) regarding the use of yijing 逸經 during the Western Han may deepen our perplexity.

The yi 逸 in the term yijing means “to be left out” (Yang Bojun, 1981: p. L, 1984: p. 197) A yijing thus refers to a jing (經 classic text) that was not adopted in the imperially authorized curriculum of classic studies, which in turn means that the study of a yijing was not a practice under imperial patronage. As Yang Bojun (1981: p. L) suggests, the Zuozhuan had long been considered a yi chunqiu 逸春秋 (i.e. an extracurricular text of $S A A$ studies) in the Han Dynasty. It was, according to Yang Bojun, considered a yi chunqiu even in the time of Wang Chong 王充 (27-97) in the Eastern Han Dynasty. This means the Zuozhuan had remained extracurricular throughout the entire Western Han era.

This, however, still does not adequately explain the lack of its reference in the Xinshu. Although the study of extracurricular classic texts (i.e. yijing) did not enjoy governmental patronage, it was not banned, either ${ }^{37}$. In fact, Wang Mao noticed that there had been a number of scholar-officials during the Western Han who actually took delight in citing such texts in their writings and speeches. The people Wang Mao listed were mostly scholar-officials after Jia Yi's time. But, on the list there was also Xiao He 蕭何, who significantly predated Jia Yi. Wang Mao claimed to have found numerous cases of yijing-citing in the Han Dynasty. In that case, although the Zuozhuan could not possibly be used as an orthodox canon, why was it not even honored in the Xinshu in the capacity of a yijing? And, as a logical question to follow, could the author of the Xinshu still be someone specialized in Zuozhuan study, living in a time when yijing-citing was at least perfectly acceptable if not nec-

\footnotetext{
${ }^{37}$ As scholars during the reign of Emperor Wu (r. 141-87 BC), for instance, Sima Tan 司馬談 and Sima Qian admittedly used much of the Zuozhuan in the Shiji. But the Shiji was a private undertaking rather than an officially commissioned compilation. As Wang Guowei 王國維 (1973: Vol. 11, shilin 3, p. 513) pointed out, the Shiji was “a work composed in privacy” 私 家著述, which its author did not dedicate to the imperial court. This being the case, the use of the Zuozhuan in the Shiji neither disproves the status of the Zuozhuan as a yijing nor indicates the acceptance of the Zuozhuan by the imperial academia. The unofficial nature of the Shiji is not only noted in the scholarship on the historical literature of pre-modern China (e.g. Loewe, 1966: p. 281), but also reflected in Sima Qian's own postscript to the Shiji. (i.e. “Taishigong zixu” 太史公自序) In the postscript, Sima Qian stated that he had composed the Shiji to convey “one scholar's view”一家之言, which he would save for the “sages and worthies of later generations” 後世聖人君 子 rather than present it to his contemporaries. Sima Qian, in addition, expressed the same idea in his letter to Ren An 任安.
}

essarily fashionable?

My answer to these questions is invariably affirmative. We need, firstly, examine the transmission of the Zuozhuan during the Western Han. In spite of the long transmission that the Zuozhuan school of SAA studies had undergone, the Zuozhuan never became a popular classic in the imperial court until the reign of Emperor Ping of the dynasty (r. 1 BC-6 AD), which was over 160 years after Jia Yi's death. Previously, during Emperor Ai's (r. 6-1 BC) time, the Zuozhuan school once attempted to establish an official institute for the Zuozhuan study. But they did so only to meet with oppositions from the Imperial Erudites (Hanshu, 1962: p. 1976). Hence Pi Xirui 皮錫瑞 (1850-1908) (1936: p. 79) agreed with Liu Chang's 劉敞 (1019-1068) that the Zuozhuan was unwelcome among Western-Han literati. In fact, this problem was so impressive among later generations of scholars that even a record of the Liu 劉 collateral group in the Zuozhuan would be enough to arouse suspicion $^{38}$. During the Western Han, the popular and official schools of $S A A$ studies in the imperial court had first been the Gongyang 公羊 tradition and then Guliang 穀梁 tradition. Yet even the prevalence of these two traditions also predated Jia Yi.

Secondly, one must take into consideration the political atmosphere in the imperial court at that time. It is generally agreed that the Western Han was a time when the imperial court largely discouraged citation of classics. As a most widely cited example, Lu Jia 陸賈, a scholar-official previous to Jia Yi, once got scolded by Emperor Gaozu for citing classics from time to time. What the emperor wanted him to do instead was to summarize the political lessons that could be drawn from the succession of the Qin Dynasty by the Han Empire (Hanshu, 1962: p. 2113).

Things did not change much in Jia Yi's generation. Emperor Wen was the ruler that Jia Yi served. From the biography of Zhang Shizhi 張釋之, we learn that this emperor would still expect an official to "lower" his arguments down to a practical level instead of "issuing very high[-sounding] theories." At such an imperial request, Zhang Shizhi, too, had to confine his topic to the lessons of the Qin-Han period (Hanshu, 1962: p. 2307).

The Xinshu are divided into such sections as shishi, lianyu, and zashi. According to Yu Jiaxi (1958: p. 541, 544), the texts in the shishi section were written to the emperor whereas those

\footnotetext{
${ }^{38}$ Liu was the surname of the royal family in the Han Dynasty. In the Zuozhuan, Lord Wen year 13, there is a sentence reading "those who remained [came to] be [known as] the Liu collateral branch” 其處者為劉氏. Kong Yinda 孔穎達 (547-648) suspected the sentence to be a deliberate interpolation by the Zuozhuan scholars of the Han times. Those scholars-such is Kong Yingda's suspicion-mixed this artificial sentence into the Zuozhuan in hope of enhancing the popularity of the Zuozhuan in their time. "Exploring [its] context," says Kong, "[one would find] the sentence odd. [I] intensely suspect that this sentence was not what [the original author] had intended [to say]. Basically, [I] think, [it was because] ancient learning was abandoned at the beginning of the Han Dynasty [and hence] Master Zuo [Qiuming's work] was not eminent in the world then. For lack of means to fulfill themselves, [those] early scholars of classics ... thus interpolated these words with a view to winning the favor of [their] generation. 討尋上 下，其文不類。深疑此句或非本旨，蓋以為漢世初興，捐棄古學，左氏 不顯於世, 先儒無以自申, ……插注此辭, 將以媚於世 (Du and Kong, 1983: Vol. 143, p. 424a). Kong's suspicion is now proven to be ill founded (see Yang Bojun, 1981: pp. 596-597). However, such suspicion itself best exemplifies the deep impression left among later generations of Chinese scholars regarding the unpopularity of the Zuozhuan during the Western Han times.
} 
in the lianyu and zashi sections were largely Jia Yi's unofficial speeches recorded by his disciples or followers. If we accept Yu Jiaxi's view, then it seems interesting that one encounters more Spring-Autumn stories in lianyu and zashi than in shishi ${ }^{39}$. As is generally known, although "high-sounding" theorization was not welcome in court, history had always been an important subject of academic discipline. By the Han Dynasty, it had been a long tradition among scholars of various persuasions to resort to history in their theoretical undertakings (Luo Jun, 1995: pp. 96-97). Although this tradition could have been affected by the political fashions of the time, it was not likely to be terminated by the fashions. What was dispensed with in the imperial court was not necessarily as dispensable in education. In Chapter "Xianxing” 先醒 in the lianyu section of the Xinshu, one can find an example where Jia Yi, as a royal tutor, taught a prince how to interpret three Spring-Autumn anecdotes. However, in education, the contents of teaching would inevitably be circumscribed by the outcome of academic and political contentions. That may account for the lack of direct citation and mention of the Zuozhuan even in those Xinshu lectures.

It was not until several decades after Jia Yi's time did the knowledge of the Zuozhuan come to be manifested in the speeches of those scholar-officials with expertise in Zuozhuan study. Liu Xin, for instance, once quoted a short passage from Zuozhuan Lord Cheng year 13 in his memorial during Emperor Cheng's reign (32-7 BC) (see Hanshu, 1962: p. 979, 980, footnote 1). Note that Liu's memorial with a quote of Zuozhuan historically heralded the Zuozhuan school's large-scaled but abortive campaign to institutionalize the Zuozhuan study in 6 $\mathrm{BC}$, the very year immediately after Emperor Cheng's reign, which means that such direct use of the Zuozhuan occurred over 130 years after Jia Yi's death. Another example is Du Ye 杜鄴, grandson of Zhang Chang 張敞, who was an official-scholar very knowledgeable about the Zuozhuan. In his early years, Du Ye had studied under Zhang Chang's son-i.e. Du's own maternal uncle-Zhang Ji 張吉 and inhered thereof the academic heritage of the Zhang family. In the year of 2 BC, Du Ye wrote a memorial to his emperor, which contained the following passage.

In the past, the Earl of Zheng yielded to Madam Jiang's wish, hence the eventual cataclysmic usurpation of power by [his younger brother] Duan. King Xiang of Zhou domestically suffered from the trouble caused by Queen [Mother] Hui, [which resulted in] his hazardous exile in Zheng. 昔鄭伯隨姜氏之欲, 終有叔段篡國之禍; 周襄 王內迫惠后之難, 而遭居鄭之危 (Hanshu, 1962: p. 3475).

This is a passage featuring forthright citations of Zuozhuan

\footnotetext{
${ }^{39}$ The Spring-Autumn stories in the shishi section are both few and brief. The only exception in this regard is Chapter "Shenwei." But this chapter, if we recall Li Xueqin’s 李學勤 (1989: p. 5) judgment, is written in the genre of wei 微. Unlike other articles in this section, “Shenwei” bears no evidence to indicate that it was a petition addressed to the court. For one thing, an author of a petition would refer to himself as chen 臣 and the emperor as bixia 陛下. But neither of these is found in "Shenwei." In fact "Shenwei” is simply not composed in the form of a petition or correspondence, where the author directly addressed another person or a certain sector of the government. Rather, "Shenwei" squarely meets Li Xueqin's description of the genre wei insofar as it is a moralistic discussion. As such, it contains elaborate presentations of four Spring-Autumn anecdotes; though, as scholars have pointed out, the stories significantly differ from their counterparts in the Zuozhuan.
}

Lord Yin year 1 and Lord Xi year 24 (Yang Shuda, 1984: Vol. 9 , p. 658 $)^{40}$. As an official message to the court, perhaps it was no coincidence that this occurred squarely in the thriving period of the Zuozhuan school in the Western Han-though the Zuozhuan study was still not institutionalized at that time. By the time this message was written, over 160 years had elapsed since Jia Yi's death. And it is noteworthy that the memorials of Liu Xin and Du Ye both emerged at a time when the Western Han Empire was approaching its collapse. The official establishment of the Zuozhuan as an orthodox canon took place in the Eastern Han Dynasty (25-220), which was historically a separate era from the Western Han.

Political contentions during the early Western Han are known to have been complicated by the competitions among schools of thoughts. One glaring example is found in the vying between Confucianism and Huang-Lao Daoism. By overtly citing and emphasizing the Zuozhuan in political discourse, a scholarofficial might risk inviting otherwise avoidable frictions and hostilities in court. The frictions might come from both the throne and the official-scholar's colleagues. Considering both this background and the fragmented condition of the Xinshu, one can hardly exclude the possibility that certain bamboo texts about the Zuozhuan were simply ripped off and destroyed ${ }^{41}$. Forgery, therefore, can hardly be the best-still less the soleexplanation of the lack of references to the Zuozhuan in the Xinshu.

\section{Conclusion}

The textual corruption of the Xinshu is a plain fact from which one can deduce neither way regarding the issue of its authenticity. However, the use of an embedded end title in its textual layout is found to be consistent with Western Han format of texts. A forger aware of this early format would have tried to forge more of such titles and make each of them showier or more ostentatious than the only end title "wumei". Conversely, a forger who was ignorant about this early format would not have thought to end an already complete sentence with a redundant disyllabic word in the first place. Either way, we start from hypothesizing the forgery of the text but end in disproving the hypothesis.

But does this signify the authenticity of the text? We must reiterate our earlier concession about the inadequacy of such a single-albeit valid - piece of evidence. To textual critics who accept nothing less than definitive authenticity, I would suggest looking also for definitive evidence of forgery, because a case of forgery must be established on no less concrete evidence than should a case of authenticity. As shown in the present

\footnotetext{
${ }^{40}$ According to the edition of the Hanshu kuiguan 漢書窺管 in my possession, the latter citation is that of "Zuozhuan Lord Xi year 25". (cf. Yang Shuda, 1984: p. 1029). I suspect that its number " 25 " is a typographic error. This citation by Du Ye is a citation of Zuozhuan Lord Xi year 24, not 25.

${ }^{41}$ By the Han Dynasty, there had already been a long history of censorship in China. It is generally known that a large quantity of ancient documents was destroyed in the Qin Dynasty. But that may not have been the first case of censorship. Ban Gu noted that with the decline of the hegemonic culture of the Zhou Dynasty, various lords began to violate former norms; and, as they did so, they removed from early documents some texts about former proprieties (Hanshu, 1962: p. 1029). According to Yang Shuda (1984: Vol. 3, p. 130), Ban Gu's observation was most likely to be based on Mencius 5B: 2 . Speaking of Jia Yi, Liu Xiang was the first known compiler of Jia's writings Considering the fact tha Jia Yi and Liu Xiang were about a century apart, we cannot securely assume that Jia's works were handed down to Liu Xiang's generation complete and intact.
} 
study, no skeptics of the Xinshu have provided any adequate evidence to prove their point. The most solid basis for their skepticism is still the mere lack of any adequate proof of authenticity, which is anything but concrete evidence of forgery.

Once the invalidity of their basis is ascertained, what we see is the limitation of the dichotomy of authenticity and spuriousness itself. Individual scholars' common sense is still required in their effort to gauge the extent of a text's usability in the scholarship on its conventionally ascribed era and author. I would suggest always treating the Xinshu as a usable datum for our study of Jia Yi until the very future day dawns upon us with any concrete and unequivocal evidence of forgery discovered in textual or, better still, archaeological research.

\section{REFERENCES}

Cai Tingji 蔡廷吉 (1984). Jia Yi yanjiu 賈誼研究. Taibei: Wenshizhe Chubanshe.

Chan, W.-T. (1963). A source book in Chinese philosophy. Princeton, NJ: Princeton University.

Chao Gongwu 昆公武 (fl. 1151-1161) (1983). Junzhai dushu zhi 郡 齋讀書志. Yingyin wenyuange Siku quansh edition, Vol. 674. Taipei: Shangwu.

Chen Liang 陳亮 (1143-1194) (1987). Longchuan ji 龍川集. In Deng Guangming 鄧廣銘 (Ed.), Chen Liang ji 陳亮集. Beijing: Zhonghua.

Chen Mengjia 陳夢家 (1980). Hanjian zhui shu 漢簡綴述. Beijing: Zhonghua.

Chen Weiliang 陳煒良, Chen Bingliang 陳炳良, \& Jiang Runxun 江 潤勳 (1958). Jia Yi yanjiu 賈誼研究. Hong Kong: Qiujing Yinwu, Ltd.

Chen Zhensun 陳振孫 (1179-1262) (1983). Zhizai shulu tijie 直齋書 錄題解. Yingyin wenyuange Siku quanshu edition. Taipei: Sangwu.

Chen Zhi 陳直 (1901-1980) (1979). Hanshu xinzheng 漢書新證. Tianjin: Tianjin Renmin.

Cherniack, S. (1994). Book culture and textual transmission in Sung China. Harvard Journal of Asiatic Studies, 54, 5-125.

Cohen, A. (2000). Introduction to research in Chinese source materials. New Haven, CT: Far Eastern Publications, Yale University.

Du Yu 杜預 (222-284), \& Kong Yingda 孔穎達 (547-648) (1983). Chunqiu Zuozhuan zhu shu 春秋左傳注疏. Yingyin wenyuange Siku quanshu edition. Taipei: Shangwu.

Fang Xiangdong 方向東 (2000). Jia Yi ji huijiao jijie 賈誼集匯校集 解. Nanjing: Hehai Daxue Chubanshe.

Gardner, C. S. (1961). Chinese traditional historiography. Cambridge: Harvard University.

Gu Shi 顧實 (1876-1956) (1987). Hanshu yiwenzhi jiangshu 漢書藝 文志講疏. Shanghai: Shanghai Guji.

Gu Yanwu 顧炎武 (1613-1682) (1990). Ri zhi lu 日知錄. In Huang Rucheng 黄汝成 (1799-1837) (Ed.), Ri zhi lu jishi 日知錄集釋. Shijiazhuang: Huashan Wenyi Chubanshe.

Guoyu 國語 (4th cent.? BC) (1978). Taipei: Jiusi Chuban Youxian Gongsi.

Hanshu 漢書 (1st cent.) (1962). Beijing: Zhonghua.

He Guangyan 何廣棪 (2001). Chen Zhensun sheng zu nian xin kao 陳振孫生卒年新考. Wenxian, 87, 159-161.

Ho Che Wah 何志華, Chu Kwok Fan 朱國藩, \& Fan Sin Piu 㚞善標 (2007). The Xinshu with parallel passages from other Pre-Han and Han texts《新書》與先秦兩漢典籍重見資料彙編. Hong Kong: The Chinese University of Hong Kong.

Huang Kan 黄㑆 (1962). Wenxin diaolong zhaji 文心雕龍札記. Beijing: Zhonghua.

Huang Yunmei 黃雲眉 (1980). Gujin weishu kao buzheng 古今偽書 考補證. Jinan: Qilu Shushe, 1980).
Jia Yi 賈誼 (200-168 BC) (1937). Xinshu 新書. Congshu jicheng chubian edition. Shanghai: Shangwu.

Jiang Boqian 蔣伯潛 (1990). Jiaochou muluxue zuanyao 校雔目錄學 纂要. Beijing: Beijing Daxue.

Knoblock, J. (1988). Xunzi: A translation and study of the complete works. Stanford: Stanford University Press.

Lewis, M. E. (1990). Sanctioned violence in early China. New York: State University of New York.

Li Xueqin 李學勤 (1989). Boshu Chunqiu shiyu yu Zuozhuan de chuanliu 帛書《春秋事語》與《左傳》的傳流. Guji zhengli yanjiu xuekan, 20, 1-6.

Liji 禮記 (1st cent. BC) (1983). Yingyin wenyuange Siku quanshu edition, Vols. 115-116. Taipei: Shangwu.

Liu Fengliu 劉逢祿 (1776-1829) (1995). Zuoshi Chunqiu kaozheng 左氏春秋考證. Xuxiu Siku quanshu edition. Shanghai: Shanghai Guji.

Luo Jun 羅焌 (1874-1932) (1995). Zhuzi xueshu 諸子學述. Changsha: Yuelu Shushe.

Luo, S. (2002). Inadequacy of Karlgren's linguistic method as seen in Rune Svarverud's study of the Xinshu. Journal of Chinese Linguistics, 31.2, 270-299.

Needham, J. et al. (1954-1999). Science and civilization in China. London: Cambridge University.

Nylan, M. (1993). Hsin shu. In M. Loewe (Ed.), Early Chinese texts: A bibliographical guide. Berkeley: Institute of East Asian Studies, University of California.

Qi Yuzhang 祁玉章 (1969). Jiazi tanwei 賈子探微. Taipei: Sanmin Shuju.

Qian Zhongshu 錢鍾書 (1979). Guan zhui bian 管錐編. Beijing: Zhonghua.

Shiji 史記 (1st cent. BC) (1963). Beijing: Zhonghua.

Shuihudi qinmu zhujian 睡虎地秦墓竹簡 (4th?-3rd? BC) (1978). Beijing: Wenwu.

Siku quanshu zongmu tiyao 四庫全書總目提要 (1724-1805) (1933). Shanghai: Shangwu.

Su Shi 蘇軾 (1037-1101) (1986). Wenzhong Su Shi wenji 文忠蘇軾 文集 (prefaced 1173). In Su Dongpo quanji 蘇東坡全集. Beijing: Beijing Shi Zhongguo Shudian.

Suishu 隋書 (7th cent.) (1973). Beijing: Zhonghua

Sun Qinshan 孙欽善, Wei Jiangong 魏建功, Wu jingcun 吳競存, \& Yin Falu 陰法魯 (1961). Guanyu Jia Yi Xinshu zhenwei wenti de tansuo 關於賈誼新書真偽問題的探索. Beijing Daxue xuebao, 5 .

Svarverud, R. (1998). Methods of the way: Early Chinese ethical thought. Leiden \& Boston: Brill.

Svarverud, R. (2000). Jia Yi Xinshu zhi chuanshi bianjie 賈誼《新書》 之傳世辨解. Wenxian, 84, 12-31.

Wang Fuzhi 王夫之 (1619-1692) (1996). Du Tongjian lun 讀通鑒論. In Chuanshan Quanshu Bianji Weiyuanhui (Ed.), Chuanshan quanshu 船山全書 (Vol. 10). Changsha: Yuelu Shushe.

Wang Guowei 王國維 (1877-1927) (1973). Guantang ji lin 觀堂集林. Hong Kong: Zhonghua.

Wang Li 王莉 (2003). Chunqiu shiyu yanjiu erti 《春秋事語》研究二 題. Guji zhengli yanjiu xuekan, 105, 42-45.

Wang Liqi 王利器 (1999). Wang Liqi xueshu 王利器學述. Hangzhou: Zhejiang Renmin Chubanshe.

Wang Mao 王柕 (1151-1213) (1939). Yeke congshu 野客論叢, Changsha: Shangwu.

Wang Yinglin 王應麟 (1223-1296) (1987). Yuhai 玉海. Beijing: Wenwu.

Wang Zhouming 王洲明 (1982). Xinshu fei weishu kao 新書非偽書 考. Wenxue Yichan, 17-28.

Wang Zhong 汪中 (1744-1794) (1869). Shu xue 述學. Yangzhou: Yangzhou Shuju.

Wang Z. M., \& Xu Chao 徐超 (1996). Jia Yi ji jiaozhu 賈誼集校注. Beijing: Renmin Wenxue.

Wu Chengshi 吳承仕 (1885-1939) (1984). Jiangdian shiwen xulu 
shuzheng 經典釋文序錄疏證. Beijing: Zhonghua.

Wu Rongzeng 吳榮曾 (1998). Du boben Chunqiu shiyu 讀帛本《春 秋事語》. Wenwu, 501.

Wu Yun 吳雲, \& Li Chuntai 李春臺 (1989). Jia Yi ji jiaozhu 賈誼集 校注. Zhengzhou: Zhengzhou Guji Chubanshe.

Xunzi 荀子 (1st cent. BC) (1936). In X. Q. Wang 王先謙 (1842-1918) (Ed.), Xunzi jijie 荀子集解. Shanghai: Shangwu.

Yan Changyao 顔昌嶢 (1868-1944) (1996). Guangzi jiao shi 管子校 釋. Changsha: Yuelu Shushe.

Yan Ruoqu 閻若璩 (1636-1704) (1796). Shangshu guwen shuzheng 尚書古文疏證. Tianjin: Wushi Kanben.

Yan Zhenyi 閻振益, \& Zhong Xia 鐘夏 (2000). Xinshu jianzhu 新書 校注. Beijing: Zhonghua.

Yang Bojun 楊伯峻 (1981). Chunqiu Zuozhuan zhu 春秋左傳注. Beijing: Zhonghua.

Yang Bojun 楊伯峻 (1984). Luyu yizhu 論語譯註. Hong Kong: Zhonghua.

Yang Shuda 楊樹達 (1885-1956) (1984). Hanshu kuiguan 漢書窥管. Shanghai: Shanghai Guji.

Yao Minghui 姚明煇 (fl. 1914) (1933). Hanshu yiwenzhi zhujie 漢書 藝文志注解. Shanghai: Dazhong Shuju.

Yao Nai 姚剩 (1936). Xibaoxuan wenji 惜抱軒文集. Shanghai: Shangwu.

Yates, R. D. S. (1997). Five lost classics: Tao, HuangLao, and Yin-
Yang in Han China. New York: Ballantine Books.

Yu Jiaxi 余嘉錫 (1958). Siku tiyao bianzheng 四庫提要辯證. Beijing: Kexue Chubanshe.

Yu Jiaxi 余嘉錫 (1963). Yu Jiaxi lun xue za zhu 余嘉錫論學雜著. Beijing: Zhonghua.

Zhang Binglin 章炳麟 (1868-1936) (1982). Zhang Taiyan quanji 章 太炎全集. Shanghai: Shanghai Renmin.

Zhang Binglin 章炳麟 (1995). Guoxue jiangyan lu 國學講演錄. Shanghai: Huadong Shifan Daxue Chubanshe.

Zhang Shunhui 張舜徽 (1962). Zhongguo gudai shiji jiaodu fa 中國 古代史籍校讀法. Shanghai: Zhonghua.

Zhang Shunhui 張舜徽 (1990). Hanshu yiwenzhi tongshi 漢書藝文志 通釋. Wuhan: Hubei Jiaoyu Chubanshe.

Zhang Xuecheng 章學誠 (1738-1801) (1985). Wenshi tongyi 文史通 義 Jiaochou tongyi 校倠隹通義. In Ye Ying 葉瑛 (Ed.), Wenshi tongyi jiao zhu 文史通義校注. Beijing: Zhonghua.

Zhang Zhenglang 張政烺 (1977). Chunqiu shiyu jieti 春秋事語解題. Wenwu, 248, 36-39.

Zhao Ximing 趙犧明 (1705-1787) (1937). Yanshi jiaxun (zhu) 顏氏 家訓(注). Shanghai: Shangwu.

Zhu Taiyan 朱太岩 (1989). Mantan xieke gong—Diaoke gongyi de liubian (1) 漫談寫刻工一一雕刻工藝的流變(一). Guji Zhengli Yanjiu Xuekan, 19, 46-47. 